OECDpublishing

\title{
BUSINESS \\ DYNAMICS AND \\ DIGITALISATION
}

OECD SCIENCE, TECHNOLOGY AND INNOVATION POLICY PAPERS

March 2019 No. 62 
This paper was approved and declassified by the Committee on Industry, Innovation and Entrepreneurship on 14-15 November 2018 and was prepared for publication by the OECD Secretariat.

This publication is a contribution to the OECD Going Digital project, which aims to provide policymakers with the tools they need to help their economies and societies prosper in an increasingly digital and data-driven world.

For more information, visit www.oecd.org/going-digital.

\#GoingDigital

Note to Delegations:

This document is also available on ONE M\&P under the reference code:

DSTI/CIIE(2018)14/FINAL

This document, as well as any data and any map included herein, are without prejudice to the status of or sovereignty over any territory, to the delimitation of international frontiers and boundaries and to the name of any territory, city or area.

The statistical data for Israel are supplied by and under the responsibility of the relevant Israeli authorities. The use of such data by the OECD is without prejudice to the status of the Golan Heights, East Jerusalem and Israeli settlements in the West Bank under the terms of international law.

COECD (2019)

You can copy, download or print OECD content for your own use, and you can include excerpts from OECD publications, databases and multimedia products in your own documents, presentations, blogs, websites and teaching materials, provided that suitable acknowledgment of OECD as source and copyright owner is given. All requests for commercial use and translation rights should be submitted to rights@ oecd.org. 


\section{Table of contents}

$\begin{array}{lll}1 & \text { Introduction } & 7\end{array}$

2 A brief overview of the relevant evidence 9

3 Data $\quad 11$

3.1 Business dynamics $\ldots \ldots \ldots \ldots \ldots \ldots \ldots$

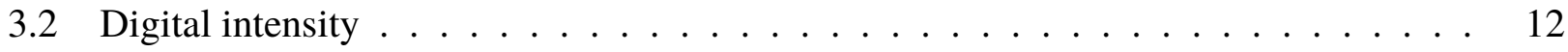

4 Stylised facts $\quad 13$

4.1 Fact 1: Digital intensive sectors are more dynamic than other sectors . . . . . . . . 15

4.1.1 This is particularly true for services . . . . . . . . . . . . . 15

4.1.2 And along most dimensions of the digital transformation . . . . . . . . 16

4.1.3 But with significant differences across countries . . . . . . . . . . . 17

4.2 Fact 2: Digital intensive sectors experience declines in dynamism after 2000 . . . . 19

4.2.1 These declines appear faster than in other sectors . . . . . . . . . . 21

4.2.2 But there are differences across countries . . . . . . . . . . . . 21

5 Potential explanations $\quad 24$

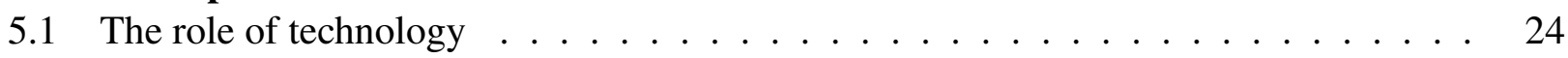

5.1.1 Consistency with other empirical findings . . . . . . . . . . . 26

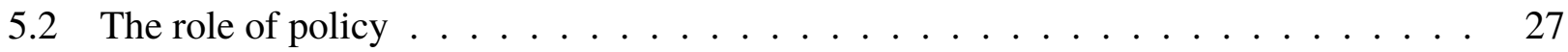

5.2.1 A guiding framework for policy-makers . . . . . . . . . . . . 27

5.2.2 Methodology and key findings . . . . . . . . . . . . . . . . 29

5.2.3 An illustration using possible policy reforms . . . . . . . . . . . . 32

6 Some conclusions $\quad 33$

$\begin{array}{ll}\text { Appendix } & 34\end{array}$

$\begin{array}{lc}\text { References } & 56\end{array}$ 


\section{List of Tables}

1 Average business dynamism by digital intensity . . . . . . . . . . . . . 15

A1 Contributors to the DynEmp project . . . . . . . . . . . . . . 37

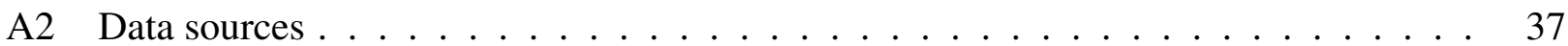

A3 Coverage of the DynEmp3 database by country over time . . . . . . . . . . . 38

A4 Industry classification table . . . . . . . . . . . . . . . . . 39

A5 Sectoral taxonomy of digital intensity: global indicator . . . . . . . . . . . . 41

A6 Average business dynamism by digital intensity - Before 2004 . . . . . . . . . . . . 46

A7 Average business dynamism by digital intensity - After 2009 . . . . . . . . . . . . 46

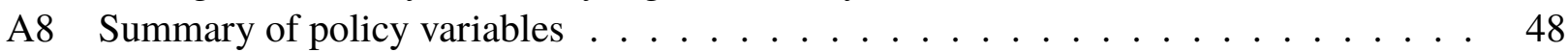

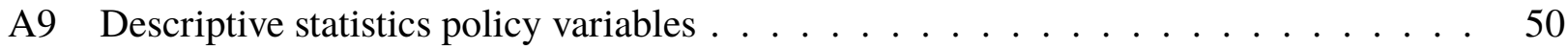

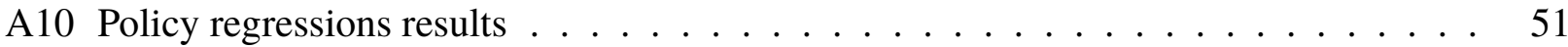

\section{List of Figures}

$1 \quad$ Business dynamics - Digital intensive and other sectors (before 2004 - after 2009) . . 13

2 Estimated elasticity of entry rates to different dimensions of digital intensity . . . . . 16

3 Cross-country differences - digital intensive vs. other sectors . . . . . . . . . . . 17

4 Change in business dynamism - Average trends . . . . . . . . . . . . . . 19

5 Cross-country differences - Change in business dynamism (digital intensive sectors) 22

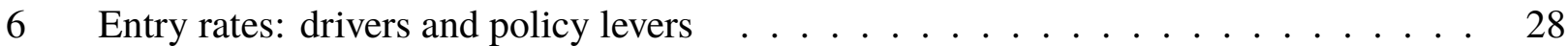

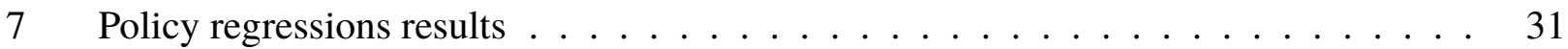

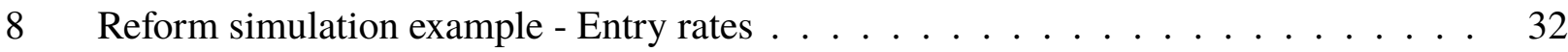

A1 Business dynamics - digital intensive vs. other sectors . . . . . . . . . . . . 43

A2 Job reallocation rates - digital intensive vs. other sectors . . . . . . . . . . 43

A3 Business dynamics variables . . . . . . . . . . . . . . . . . 44

A4 Estimated elasticity of Job reallocation rates of incumbents to different dimensions of digital intensity . . . . . . . . . . . . . . . . . . 45

A5 Change in business dynamism - Average trends . . . . . . . . . . . . 47 


\title{
BUSINESS DYNAMICS AND DIGITALISATION*
}

\author{
Flavio Calvino ${ }^{\mathrm{a}}$ and Chiara Criscuolo ${ }^{\mathrm{a}}$ \\ ${ }^{a}$ OECD Directorate for Science, Technology and Innovation
}

\begin{abstract}
This work analyses the role of the digital transformation for business dynamics across countries. The analysis combines unique harmonised data on business dynamics for 15 countries with a multi-dimensional measure of digital intensity that takes into account different facets of the digital transformation. Two key stylised facts emerge. First, digital intensive sectors - especially digital intensive services - are on average more dynamic than other sectors of the economy. Second, business dynamism has been declining in digital intensive sectors, and more so than in other sectors, especially after 2001. Despite an important role is played by technology, significant differences across countries still remain and are related to a number of institutional and policy factors.
\end{abstract}

Keywords: business dynamics; digital transformation; entrepreneurship.

*Flavio Calvino: OECD Directorate for Science, Technology and Innovation, flavio.calvino@oecd.org. Chiara Criscuolo: OECD Directorate for Science, Technology and Innovation, chiara.criscuolo@oecd.org. The authors would like to thank Sarah Box, Dirk Pilat, members of the DynEmp network (reported in Table A1 in the Appendix), participants to the OECD WPIA and CIIE meetings for the valuables comments, Isabelle Desnoyers-James and Clara Kögel for excellent statistical assistance and Rudy Verlhac for excellent research assistance and discussions. The authors would also like to thank Peter Gal and Balázs Egert for sharing a vintage of the OECD SPIDER database. Access to French data used in this work benefited from the use of Centre d'Accès Sécurisé aux Données (CASD), which is part of the "Investissements d'Avenir" program (reference: ANR-10-EQPX-17) and supported by a public grant overseen by the French National Research Agency (ANR). 


\section{Executive summary}

This work analyses the role of the digital transformation for business dynamics across countries. The analysis combines unique harmonised data on business dynamics for 15 countries with a multi-dimensional measure of digital intensity that takes into account different facets of the digital transformation.

Two key stylised facts emerge.

1. Digital intensive sectors - especially digital intensive services - are on average more dynamic than other sectors of the economy. This is consistent with digital technologies lowering entry barriers and facilitating reallocation.

2. But business dynamism has been declining in digital intensive sectors, and more so than in other sectors, especially after 2001. This decline is in line with the general purpose nature of digital technologies and with the dynamics experienced by other innovative sectors.

An important result of the analysis is that technological drivers seem to explain about $40 \%$ of the observed dynamics. However, significant differences across countries still remain and are related to institutional and policy factors.

The analysis links different policy levers to important drivers of dynamism in these sectors. The estimates point to six key policy areas that can help ensure business dynamism in digital intensive sectors:

- promoting education and training, as related to the supply and quality of entrepreneurs, especially in a rapidly changing environment

- facilitating access to finance for new ventures, particularly venture capital at seed and early stages

- stimulating potential returns to entrepreneurship

- reducing regulatory barriers to entry and administrative burdens for start-ups

- assuring a level playing field, such as efficient contract enforcement and business regulations

- avoiding excessive costs of experimentation and failure, and in particular inefficient bankruptcy procedures. 


\section{Introduction}

Digitalisation and the diffusion of Information and Communication Technologies (ICTs) have revolutionised a wide number of economic domains, favoured the emergence of new business models, and modified the way in which individuals interact, and businesses and markets operate.

In the late 1990s and early 2000s digital technologies spread very fast and, due to their pervasiveness and impact on the overall economy, they are considered general purpose technologies (GPTs) and have been often compared to innovations like electrification or the steam engine. ${ }^{1}$ In this period many new companies were set up, often starting with little means (sometimes literally starting business in a garage) but taking advantage of the new opportunities generated by digital technologies and how these facilitated entry.

As time went by, although many of these digital start-ups failed, some of them gained significant market shares and have become world leaders, becoming the tech giants of today. Indeed, the current policy debate is focusing more and more on the ongoing changes of the market environment and how these are related to digital technologies. ${ }^{2}$

In this context, this work analyses the role of the digital transformation for business dynamics across countries, with a particular focus on firm entry, exit, and job reallocation, i.e., the simultaneous job creation and job destruction in incumbent firms. The analysis combines unique harmonised data on business dynamics based on administrative sources covering the population of firms for 15 countries in the last two decades with a multi-dimensional measure of digital intensity that takes into account different facets of the digital transformation. Two key stylised facts emerge.

First, digital intensive sectors - especially digital intensive services - are on average more dynamic than other sectors of the economy, exhibiting higher entry rates and higher job reallocation rates. This is consistent with the idea that these technologies lower entry barriers and tend to facilitate reallocation. These patterns are generally confirmed also when distinguishing among different facets of the digital transformation.

Second, focusing on the evolution of business dynamism over the last 20 years, the analysis shows that it has been declining in digital intensive sectors, especially after 2001. This pattern appears linked to technological diffusion and has also characterised a number of innovative industries in the past but, in this particular case, may have been further boosted by network externalities and the general purpose nature of digital technologies. Interestingly, this decline appears faster than the one occurring in other sectors of the economy.

Even though these two stylised facts hold across countries, significant cross-country differences are evident in the patterns and dynamics of digital intensive sectors. In fact, the analysis quantifies that between 35 and $40 \%$ of the dynamics in digital intensive sectors can be explained by technological change while about $40 \%$ is linked to country-specific factors.

Econometric analysis relates these cross-country differences to institutional and policy factors, providing a guiding framework for policy-makers in this area. The estimates point to the importance for business dynamism of six policy drivers: i) promoting education and training, as related to the supply and quality of entrepreneurs, especially in a rapidly changing environment; ii) facilitating access to finance for new ventures, particularly venture capital at seed and early stages; iii) stimulating potential returns to entrepreneurship; iv) reducing regulatory barriers to entry and administrative burdens for start-ups; v) assuring a level playing field, such as efficient contract enforcement and business regulations; vi) avoiding excessive costs of experimentation 
and failure, and in particular inefficient bankruptcy procedures.

The paper is particularly novel as it takes advantage of newly collected measures of business dynamism (entry rates, exit rates, job reallocation rates of incumbents) based on confidential highly representative data from 15 countries, ${ }^{3}$ sourced mainly from business registers, that are aggregated in a harmonised way at detailed level in the context of the OECD DynEmp project.

These data are combined with a recently developed taxonomy that ranks sectors according to their digital intensity, aiming at characterising the digital transformation in its technological component (using the share of ICT tangible and intangible investments and the share of intermediate purchases of ICT goods and services); the human capital required (focusing on the share of ICT specialists in total employment); the way it changes how markets operate (proxied by the share of turnover from online sales); and the extent to which automation is occurring (using the stock of robots per hundreds of employees) in different sectors of the economy. ${ }^{4}$

The stylised facts described, their interpretation, and the econometric analysis presented are particularly relevant as they contribute to the debate on declining business dynamism, on the economic implications of the digital transformation and the role of framework conditions, policies and institutions in the digital era.

The rest of the paper is organised as follows. Section 2 provides an overview of the relevant evidence in the context of the current debate; section 3 describes the data used to measure business dynamics across countries and the digital intensity of sectors, while section 4 presents the stylised facts that have been discussed above. Section 5 discusses the findings, providing an economic interpretation of the observed dynamics and highlighting the role of policy and institutions, while section 6 concludes and points to possible directions for future research. 


\section{A brief overview of the relevant evidence}

Digitalisation ${ }^{5}$ and the diffusion of ICTs have revolutionised a wide number of economic domains, favoured the emergence of new business models, and modified the way in which individuals interact, and businesses and markets operate.

One of the key challenges when focusing on the digital transformation is its definition and measurement. The literature that measures the digital transformation is wide and, given the complexity and pervasiveness of the phenomenon, it is not easy to adopt an unequivocal definition of digitalisation. Sectoral features however importantly mediate the overall effects of digitalisation on aggregate economic performance and business dynamics.

In this context, Calvino et al. (2018a) develop a taxonomy of digital intensive sectors classifying economic activities according to different dimensions of digital intensity. Additional discussion about this approach is presented in the following section, since this is the key measure of digital intensity used in this work. The interested reader can find all the methodological details in Calvino et al. (2018a). ${ }^{6}$

A considerable part of the literature has focused on the effects of digital technologies on different outcome variables, including employment dynamics, composition of employment, and productivity. ${ }^{7}$ Direct analyses of the links between business dynamics and digitalisation appear somewhat limited.

However, a recent strand of related literature has highlighted a significant slowdown in business dynamism over the last 15 years. This has been extensively debated in the United States (see Decker et al., 2016; Decker et al., 2018 among others), where the last two decades featured a general decline in job reallocation rates - not entirely explained by declining start-up rates and changes in the firm age distribution - accompanied by a substantial decline in the share of high growth firms, especially young ones (Decker et al., 2016; Pugsley and Sahin, 2019). This overall decline in business dynamism appears as a phenomenon with a broader scale, and ongoing OECD work is exploring its pervasiveness across countries and its possible causes (Calvino et al., 2018c).

Interestingly, important declines occurred in the US high-tech and information services sectors especially after the early 2000s, which have followed significant rising trends in the second half of the 1990s (Haltiwanger et al., 2014). Similar evidence has been also documented for Belgium by Bijnens and Konings (2018). ${ }^{8}$

ICTs are general purpose technologies (GPTs) that, following the definition by Bresnahan and Trajtenberg (1995), are characterised by their pervasiveness, improvement over time and innovation spawning. Therefore relevant evidence and lessons can be drawn from the role of technology, GPTs in particular, for business dynamics.

Indeed, on the one hand a considerable number of studies emphasise the general purpose characteristics of ICTs (Bresnahan, 2010; Jovanovic and Rousseau, 2005). In particular, Jovanovic and Rousseau (2005) discuss similarities and differences between the electrification and the IT era. Jovanovic and Rousseau (2005) highlight important analogies among the two eras, despite the fact that electrification has been more pervasive, IT has improved over time faster and induced significant innovation spawning.

On the other hand, a large body of literature focuses on the nature and diffusion of technologies and their role for industrial dynamics (see Cohen, 2010; Dosi and Nelson, 2010 for extensive discussion). In this framework, the seminal paper by Klepper (1996) summarises and formalises 
regularities regarding how entry, exit, market structure and innovation vary over the life cycle of innovative industries.

Klepper (1996) highlights that at the beginning of the industry life-cycle entry is high, the number of producers grow, market shares change rapidly and significant product innovations occur, disproportionately accounted by new entrants, with firms offering many competing versions of the industry product. As the industry evolves, entry declines, there is a shakeout in the number of producers, while output will continue to grow, the industry leadership stabilises, product innovation and the diversity of varieties decline with firms devoting increasing efforts to process innovation.

These patterns are recurrent in the analysis of innovative industries (see Klepper, 2002 for evidence about automobiles, tires, televisions, and penicillin; see also Peltoniemi, 2011 for a survey) and appear particularly relevant for the current paper, as discussed in the following sections. ${ }^{9}$

This analysis of business dynamism is part of a broader agenda aimed at documenting and understanding more general trends in industrial change and market dynamics linked with the digital transformation.

This study is therefore related to an emerging literature on technology, concentration, productivity divergence and mark-ups (see Bessen, 2017; Berlingieri et al., 2017; Bajgar et al., 2019; Calligaris et al., 2018), part of which discusses the role of digitalisation in the emergence of winner-takes-most dynamics, due to network externalities and economies of scale facilitated by ICTs (Brynjolfsson et al., 2007; Andrews et al., 2016), and to the role of super-star firms (Autor et al., 2017). A comprehensive overview and discussion of this literature is offered by Van Reenen (2018). 


\section{Data}

This section describes the data sources and procedures used to measure business dynamics across countries and the digital intensity of sectors.

\subsection{Business dynamics}

The measures of business dynamism used in this paper are based on highly representative confidential data across 15 countries, sourced mainly from business registers, that are aggregated in a harmonised way at detailed level (micro-aggregated) within the OECD DynEmp project, as discussed more in detail in Box $1 .^{10}$

\section{Box 1. The DynEmp Project}

The distributed micro-data approach adopted in the DynEmp project is based on a common statistical code developed by the OECD DynEmp team which is run in a decentralised manner by national experts from statistical agencies, academia, ministries or other public institutions, who have access to the national micro-level data. The micro-aggregated data generated by the centrally designed but locally executed program codes are then sent back for comparative cross-country analysis to the OECD.

These data reduce confidentiality concerns as they aggregate information at a sufficiently high level, and achieve a high degree of harmonisation as the definition of the extracted information is the same, ensured by the centrally written computer routine. The experts also implement country-specific disclosure procedures in order to ensure that confidentiality requirements are respected.

The first phase of the project was implemented in the first half of 2013 and was called DynEmp Express. This first phase was based on a simplified statistical code which led to the collection of a database at national level covering 18 countries (see Criscuolo et al., 2014). The second phase of the project, called DynEmp v.2, aimed at building a database which contains more detailed data on the within-sector contribution of start-ups and young firms to employment growth, and allowed to analyse in detail the role played by national policies and framework conditions for employment dynamics (see for instance Calvino et al., 2016; Calvino et al., 2018b).

This paper is based on the third wave of data collection at its current stage, featuring a more sophisticated statistical routine called DynEmp3. Novelties include additional adjustments the employment variables to proxy total employment in the calendar year, additional aggregations, variables and distributed regressions.

Recently, the DynEmp code has been modified to analyse employment and business dynamics at the regional and local level (Calvino and Criscuolo, 2017), as well as to run on cross-sectional databases that do not allow a panel dimension. 
The high representativeness of the underlying data sources, the harmonisation of the variables computed and the large country coverage are three key features that make the DynEmp dataset unique and particularly suitable for the present investigation.

Countries used in this paper include Austria, Belgium, Brazil, Costa Rica, Finland, France, Hungary, Italy, Japan, the Netherlands, Norway, Portugal, Spain, Sweden, and Turkey. ${ }^{11}$

The time coverage of the database varies from country to country, with highest cross-country coverage in the period between 1998 and 2015, which is going to be the focus of the current analysis. Details on the underlying data sources (Table A2) and a detailed coverage table (Table A3) are reported in the Appendix.

The analysis uses three key industry-level variables to measure business dynamism: i) entry rates; ii) exit rates; iii) job reallocation rates of incumbents. ${ }^{12}$ These represent the key margins of variation of business dynamism i.e, the extent to which new firms enter the market, their exit, and the extent to which job reallocation occurs among incumbent firms. ${ }^{13}$ A more detailed methodological description of the variables and detailed definitions are reported in the Appendix. ${ }^{14}$

The industry aggregation used in the DynEmp3 database follows the OECD STAN A38 industry classification, i.e., approximately a 2-digit industry aggregation. The focus is restricted to manufacturing and non-financial market services. ${ }^{15}$

\subsection{Digital intensity}

The key indicator of digitalisation used in this paper is based on the work by Calvino et al. (2018a). They develop a taxonomy of digital intensive sectors classifying economic activities according to different dimension of digital intensity. The approach used by Calvino et al. (2018a) starts from two considerations: first, the digital transformation is a complex phenomenon that is hardly captured by a single indicator; second, different sectors of activity are affected by digital technologies in heterogeneous ways.

In this framework, Calvino et al. (2018a) build different measures of the digital transformation in sectors aiming at representing digitalisation in i) its technological component (using the share of ICT tangible and intangible investments and the share of intermediate purchases of ICT goods and services), ii) the human capital required (focusing on the share of ICT specialists in total employment), iii) the way it changes how markets operate (proxied by the share of turnover from online sales), and iv) the extent to which automation is occurring (using the stock of robots per hundreds of employees). Methodological details are discussed at length in Calvino et al. (2018a).

On the basis of the above described dimensions, Calvino et al. (2018a) propose an overall summary indicator that attempts to summarise the different facets of the digital transformation. ${ }^{16}$ This summary indicator is available for two time periods (2001-03 and 2013-15). As highlighted in Calvino et al. (2018a), sectors ranked in the top quartile (high digital intensive) exhibit a considerable degree of persistence. In this context, the definition of digital intensive sectors used in this paper combines sectors ranked in the top quartile in either of the two periods.

Given the focus of the current paper (on manufacturing and non-financial market services), this results in the following digital intensive sectors: Computer and electronics; Machinery and equipment n.e.c.; Transport equipment; Telecommunication; IT; Legal and accounting; Scientific R\&D; Marketing and other business services; Administrative and support services. ${ }^{17}$ A summary table classifying sectors according to their digital intensity is reported in the Appendix (Table A5). 


\section{Stylised facts}

This section analyses business dynamics focusing on the patterns and dynamics of digital intensive sectors, and compares them with other sectors of the economy, focusing on the three margins discussed above (entry rates, exit rates, and job reallocation rates of incumbents). Two main stylised facts are presented below.

A first descriptive analysis is provided in Figure 1, which shows these three margins by country focusing separately on digital intensive sectors and other sectors of the economy. ${ }^{18}$

This figure already highlights that i) digital intensive sectors appear on average more dynamic than other sectors, and ii) that they have experienced significant declines in dynamism. These two facts are examined in detail in the following, taking into account a wide range of potential confounding factors.

Figure 1. Business dynamics - Digital intensive and other sectors (before 2004 - after 2009)

(a) Job reallocation rate of incumbents

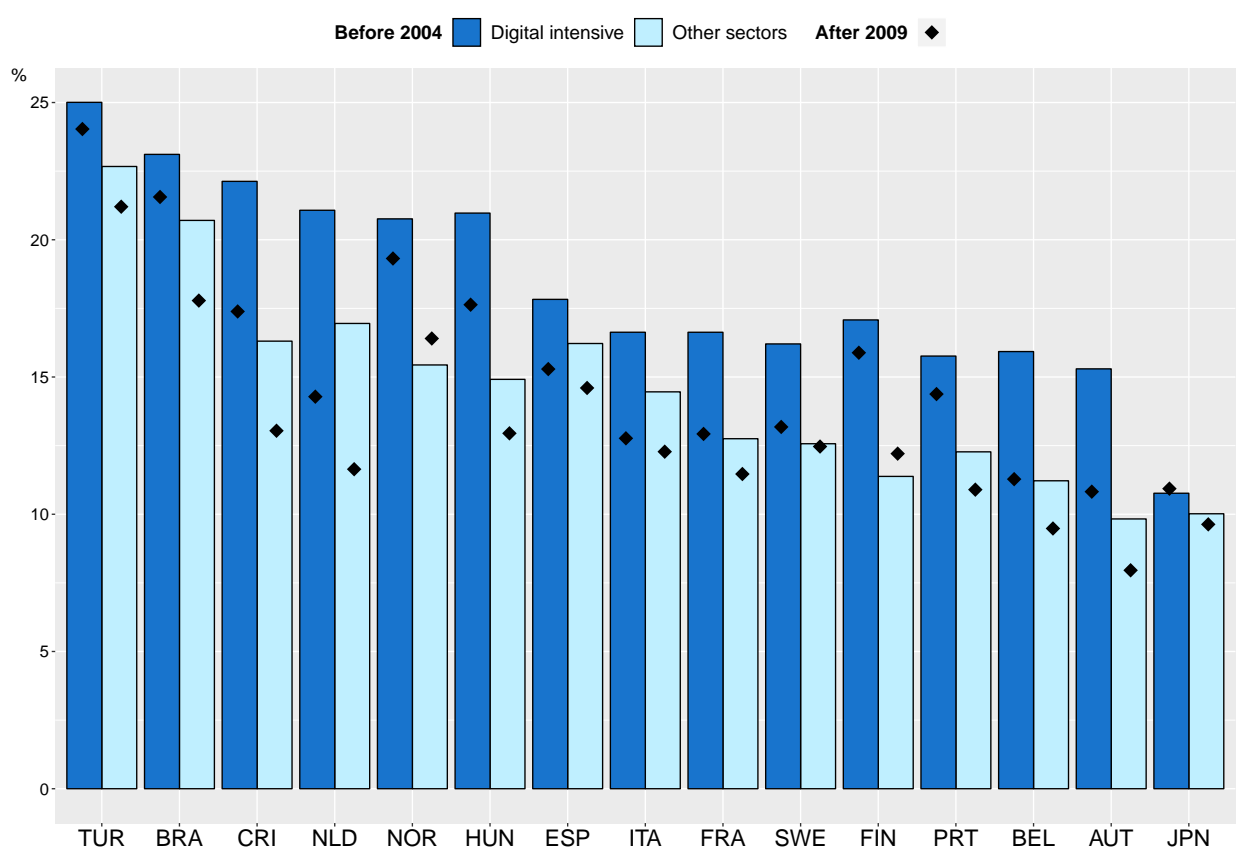


(b) Entry rates

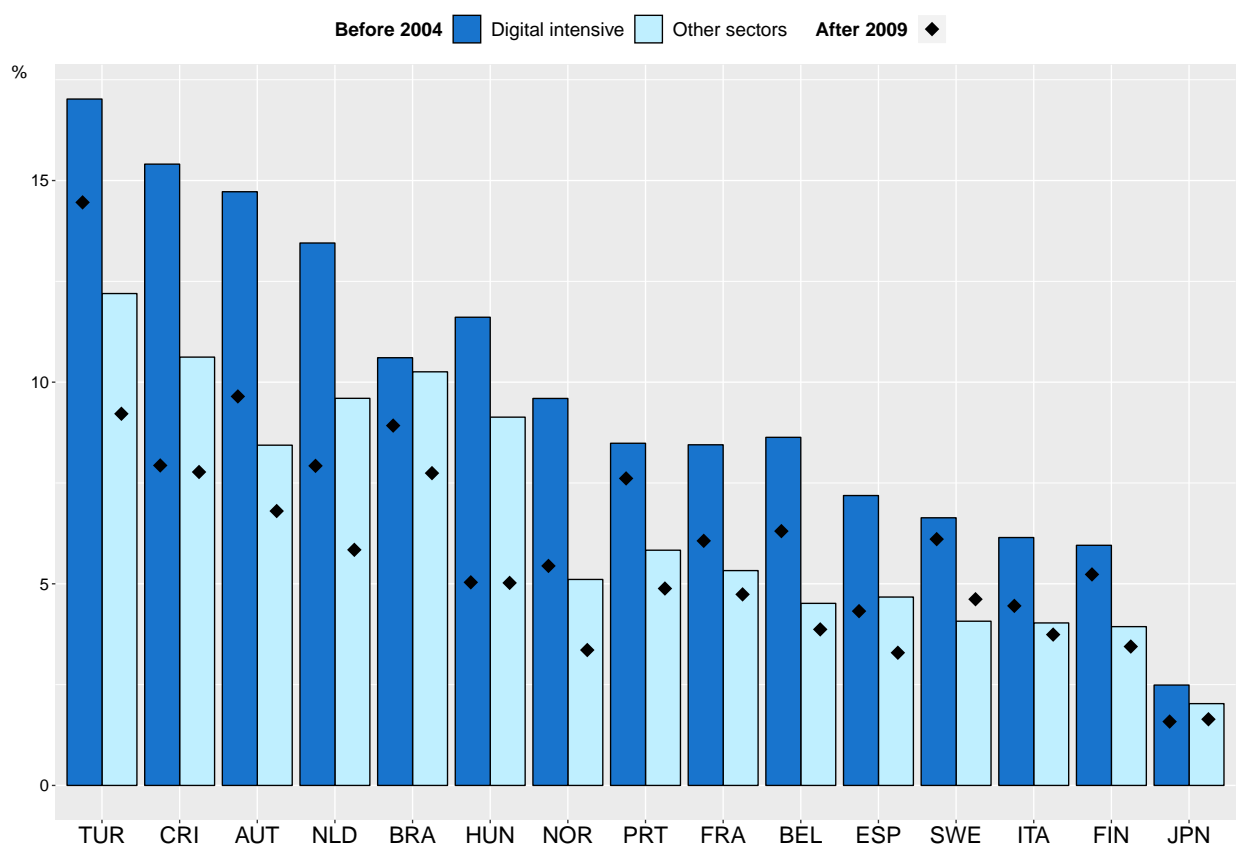

(c) Exit rates

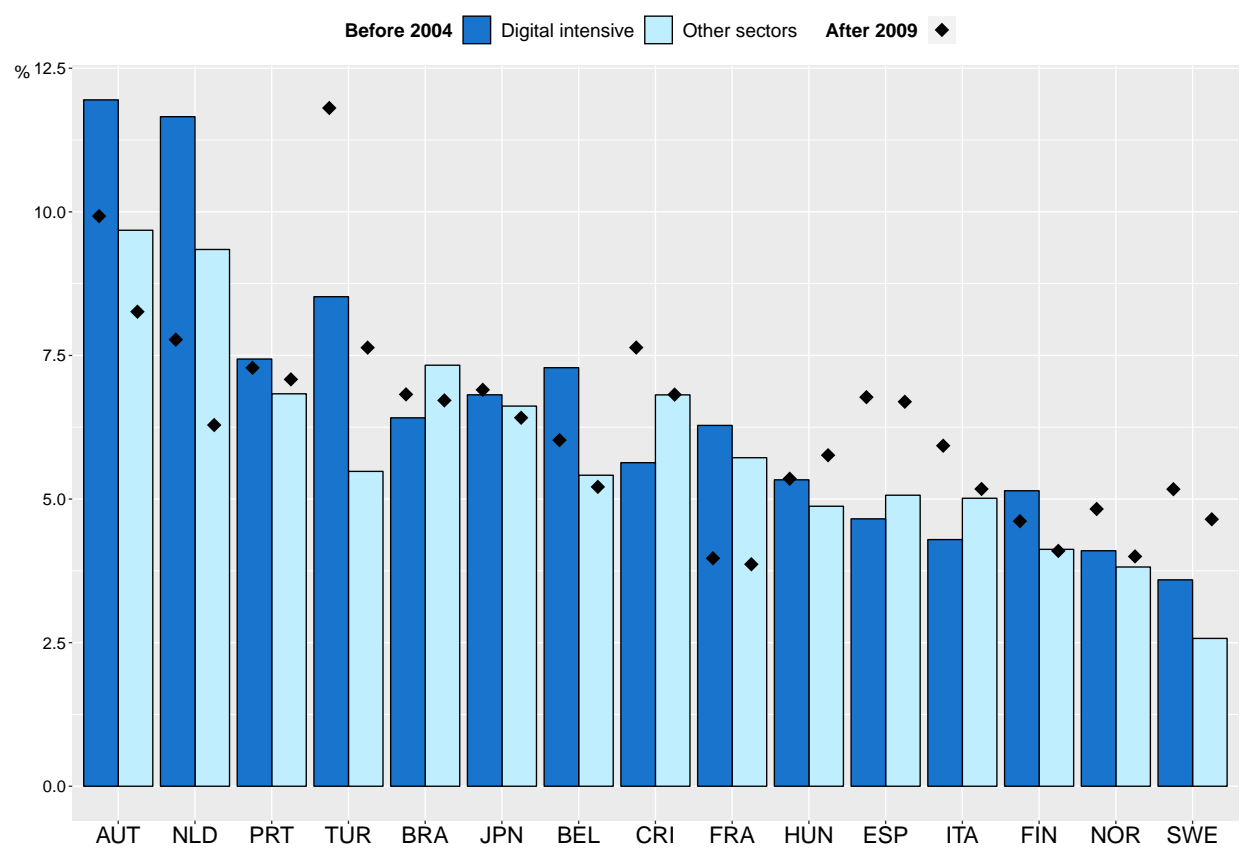

Note: The bars report for each country unweighted averages across STAN a38 sectors and available years, focusing separately on the groups of digital intensive and other sectors, for two periods (before 2004 and after 2009). For Costa Rica, Spain, the Netherlands, and Turkey the first available year is used for the first (before 2004) period. A detailed coverage table is reported in the Appendix (Table A3). Owing to methodological differences, figures may deviate from officially published national statistics. Data for some countries are still preliminary.

Source: OECD DynEmp3 database, August 2018. 


\subsection{Fact 1: Digital intensive sectors are more dynamic than other sectors}

The analysis focuses on business dynamics of digital intensive sectors with respect to other sectors of the economy and shows that on average digital intensive sectors are more dynamic than the rest of the economy.

As shown in Table 1, digital intensive sectors are characterised by higher average entry and job reallocation rates of incumbent firms, even after controlling for unobserved country-specific macro-economic shocks (Figure A1 in the Appendix). ${ }^{19}$

Despite exit rates do not appear significantly different form those experienced by other sectors of the economy (Figure A1 in the Appendix), focusing on overall job reallocation rates (for all firms) confirms that on average digital intensive sectors are more dynamic than other sectors (see Figure A2 in the Appendix). ${ }^{20}$ Moreover entrants in digital intensive sectors experience a higher post-entry employment growth rates ( 3 and 5 years after entry) with respect to other sectors of the economy.

Table 1. Average business dynamism by digital intensity

\begin{tabular}{lcc|cc}
\hline & Digital & Other & \\
\hline & mean & std. dev. & mean & std. dev. \\
Job reallocation rates of incumbents (\%) & 16.6 & 6.4 & 13.4 & 4.8 \\
Entry rates (\%) & 8.0 & 4.8 & 5.7 & 3.4 \\
Exit rates (\%) & 6.5 & 3.7 & 5.8 & 2.6 \\
\hline
\end{tabular}

Note: The table reports unweighted averages and standard deviations of job reallocation rates of incumbents, entry rates, and exit rates across countries, STAN a38 sectors, and years focusing on the Digital intensive group and on Other sectors.

Source: OECD DynEmp3 database, August 2018.

\subsubsection{This is particularly true for services}

Focusing separately on manufacturing and services shows that digital intensive services appear particularly more dynamic with respect to other sectors of the economy.

Figure A3 in the Appendix indeed indicates that in digital intensive sectors incumbents have higher job reallocation rates both in manufacturing and services, while entry rates are significantly higher only in digital-intensive non-financial market services. Finally, exit rates appear similar in digital intensive and other sectors.

Focusing on overall job reallocation rates (for all firms) confirms that on average digital intensive services are more dynamic than other sectors (see Figure A2 in the Appendix). ${ }^{21}$ Moreover, entrants in digital intensive sectors experience a higher post-entry employment growth rates (3 and 5 years after entry) with respect to other sectors of the economy, both in manufacturing and in services, suggesting that digital firms can upscale more easily than firms in other sectors. 


\subsubsection{And along most dimensions of the digital transformation}

The extent to which different facets of the digital transformation are related business dynamism is explored next.

As discussed in Section 3, four aspects of the digital transformation are included in the overall digital intensity measure used: i) its technological component (using the share of ICT tangible and intangible investments and the share of intermediate purchases of ICT goods and services), ii) the human capital required (focusing on the share of ICT specialists in total employment), iii) the way it changes how markets operate (proxied by the share of turnover from online sales), and iv) the extent to which automation is occurring (using the stock of robots per hundreds of employees). ${ }^{22}$

\section{Figure 2. Estimated elasticity of entry rates to different dimensions of digital intensity}

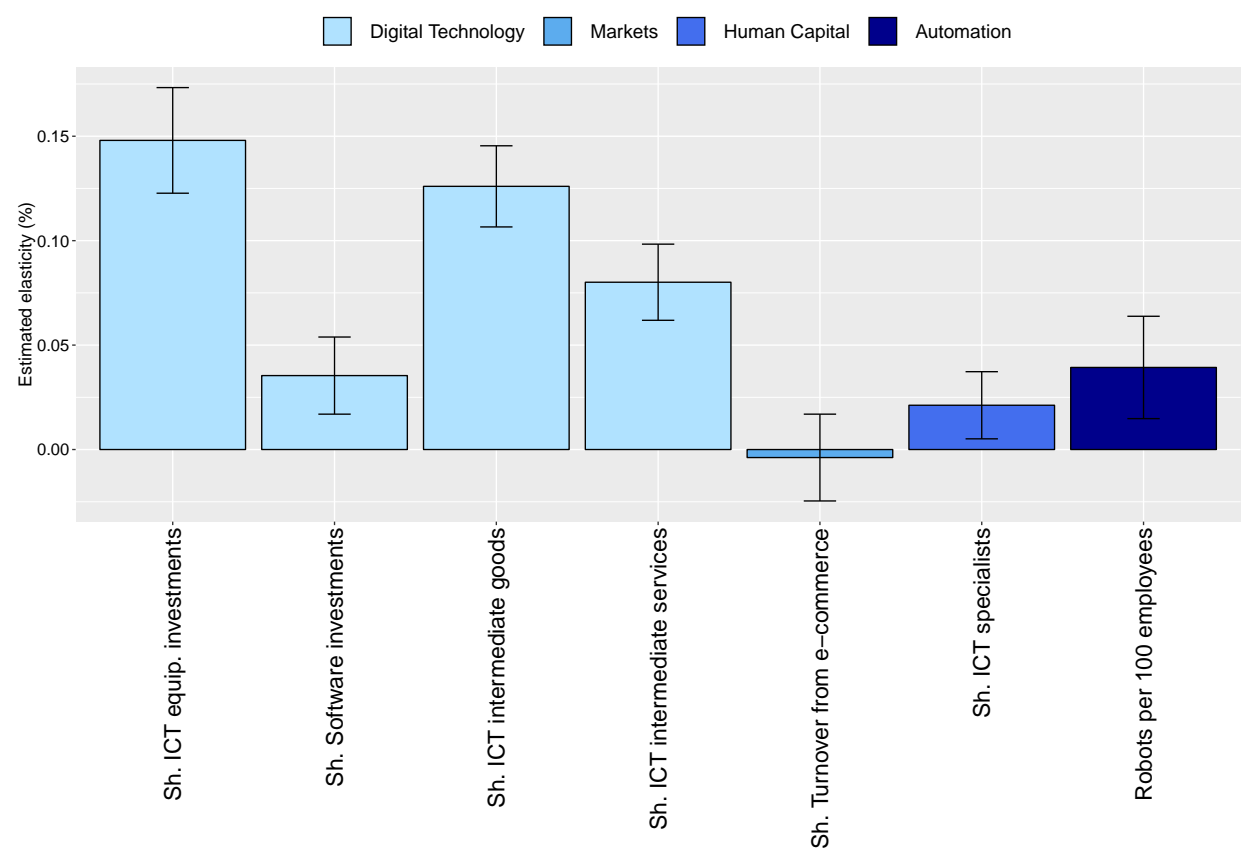

Note: The bars report coefficients (elasticities) based on separate regressions where the dependent variable is (the log of) entry rates, while the explanatory variables are (the log of) different digital intensity measures, as described in the text. The regressions include as controls a manufacturing vs. services dummy and country-year fixed effects. Confidence intervals $(95 \%)$ are also reported based on robust standard errors.

Source: OECD DynEmp3 database, August 2018.

All but one indicator of digital intensity are linked with higher entry rates (see Figure 2). Qualitatively similar results also hold when focusing on job reallocation rates of incumbent firms (Figure A4 in the Appendix). The exception being the share of turnover from electronic commerce that shows no (negative) relation with start-up rates (job reallocation rates of incumbents). This may be possibly related to the fact that sectors where a higher share of turnover is sold online may be more subject to network externalities and winner-takes-most dynamics and characterised by higher stability of jobs and, to some extent, less dynamism. 


\subsubsection{But with significant differences across countries}

While the previous stylised fact holds robustly across countries even after controlling for country-year-specific fixed effects, significant cross-country differences exist.

The following analysis (Figure 3) focuses on the three measures of business dynamism (job reallocation rates of incumbents, entry rates, and exit rates) and highlights the degree of cross-country variation. ${ }^{23}$

The cross-country analysis of incumbents' job reallocation rates (Figure 3, Panel a) confirms that - on average - in all countries digital intensive sectors exhibit higher or similar (not statistically different from zero) job reallocation rates with respect to other sectors of the economy. Similar findings also hold for entry rates, with only Costa Rica having lower entry rates in digital intensive sectors with respect to other sectors of the economy (Figure 3, Panel b).

The overall similarity of exit rates in digital intensive and other sectors discussed in the previous sections is also evident for more than half of the countries in the database (Figure 3, Panel c). Few exceptions are on the one hand Brazil, Costa Rica and Spain that exhibit lower exit rates in digital intensive sectors, and on the other hand the Netherlands and Turkey, where digital intensive sectors tend to have higher exit rates.

These figures highlight the importance of understanding the country-specific drivers behind these differences, which will be explored in Section 5.2 with a focus on policies and institutions.

\section{Figure 3. Cross-country differences - digital intensive vs. other sectors}

\section{(a) Job reallocation rate of incumbents}

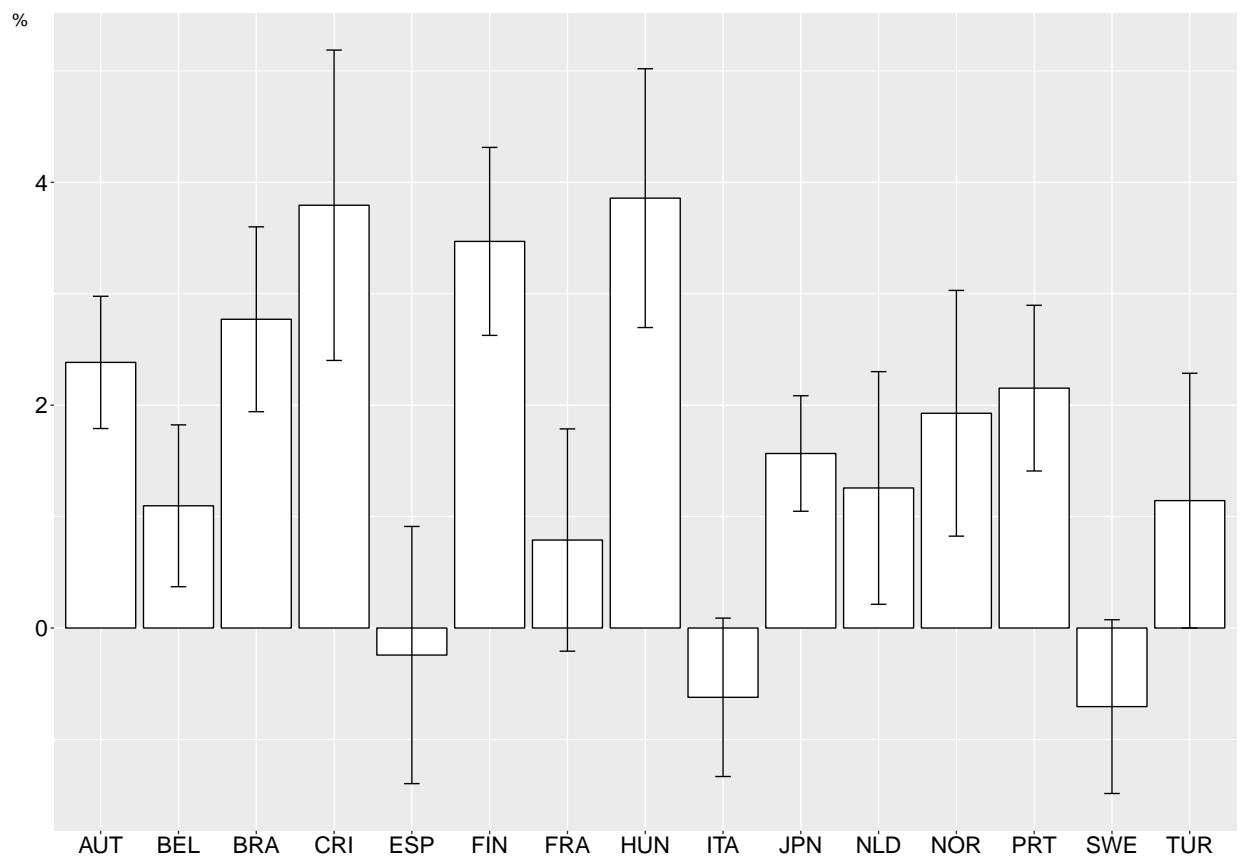




\section{(b) Entry rates}

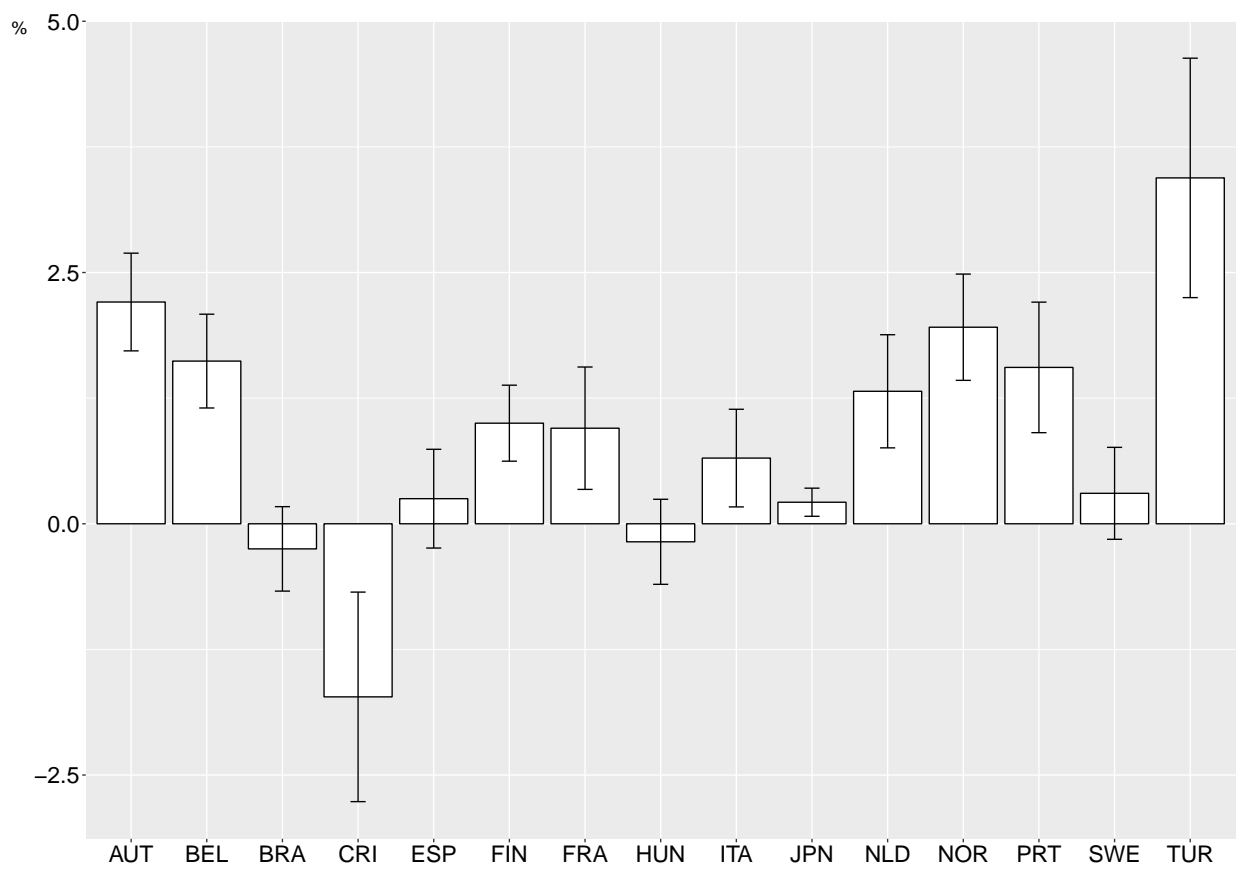

(c) Exit rates

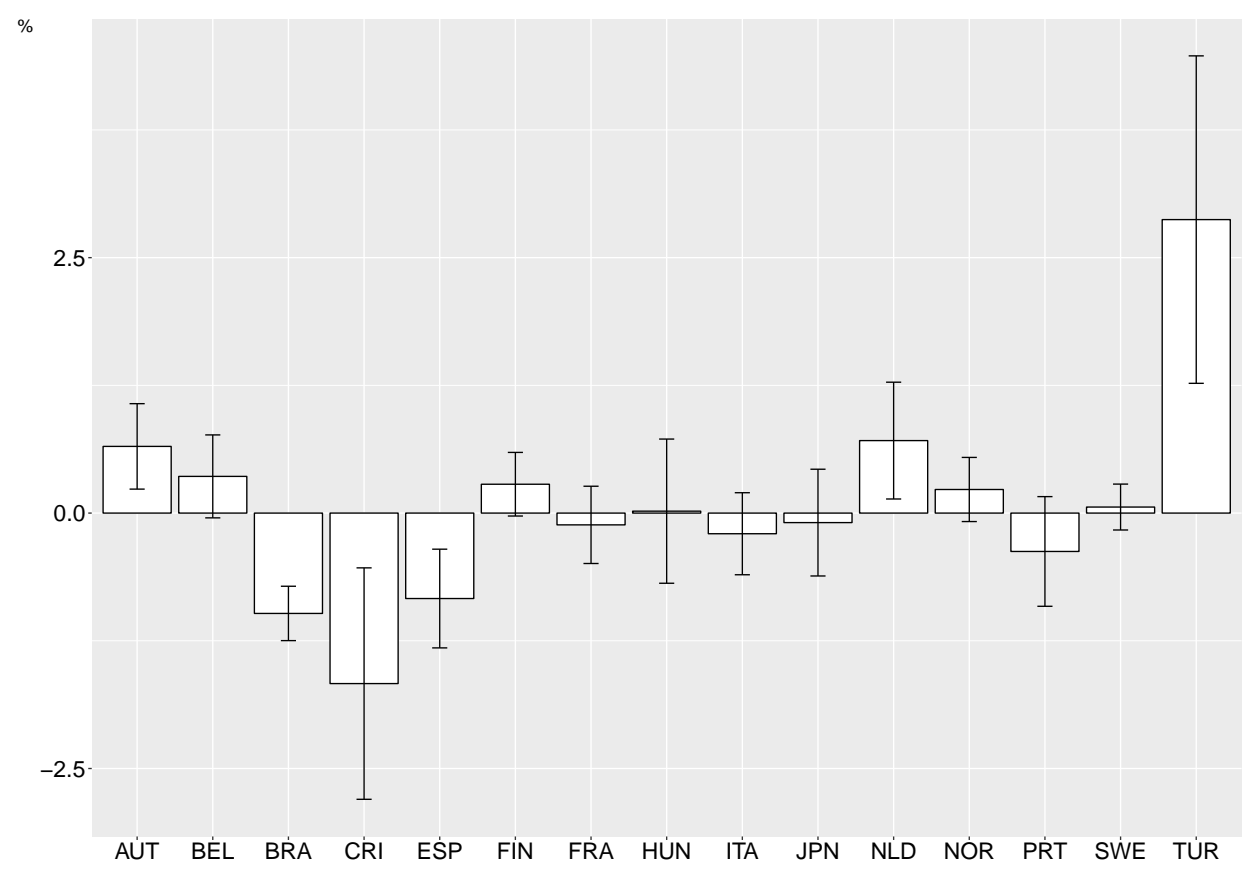

Note: The bars report coefficients based on separate country-specific regressions where the dependent variables are alternatively job reallocation rates of incumbents, entry rates or exit rates, which are regressed on a digital intensity dummy as defined above. The regressions include as controls a manufacturing vs. services dummy and year fixed effects. Confidence intervals $(95 \%)$ are also reported based on robust standard errors.

Source: OECD DynEmp3 database, August 2018. 


\subsection{Fact 2: Digital intensive sectors experience declines in dynamism after 2000}

While from a static perspective digital intensive sectors exhibit on average higher dynamism than other sectors, the picture is different when looking at trends and analysing how business dynamism has evolved across sectors and countries over time.

Figure 4 illustrates the evolution of business dynamism over time, separating digital intensive from other sectors of the economy: ${ }^{24}$ i) job reallocation rates of incumbents in digital intensive sectors (as shown in Figure 4, Panel a, solid line), is characterised by a declining trend over time, especially after the year 2000; ii) entry rates (Figure 4, Panel b, solid line) show a declining trend after 2001 is evident in digital intensive sectors, after an increasing trend in the late 1990s; while iii) exit rates (Figure 4, Panel c, solid line) exhibit a limited range of time variation (lower than $1.5 \%$ ) remaining rather stable apart from peaks around 2001 (likely linked with the dot-com bubble) and during the global financial crisis, with some increases towards the end of the period. ${ }^{25}$

Overall, a generally declining trend is also confirmed by changes in overall job reallocation rates in digital intensive sectors (Figure A5 in the Appendix, solid line), especially after 2001 and more steeply after 2010, while figures appear flatter towards the end of the period. ${ }^{26}$

Figure 4. Change in business dynamism - Average trends

\section{(a) Job reallocation rate of incumbents}

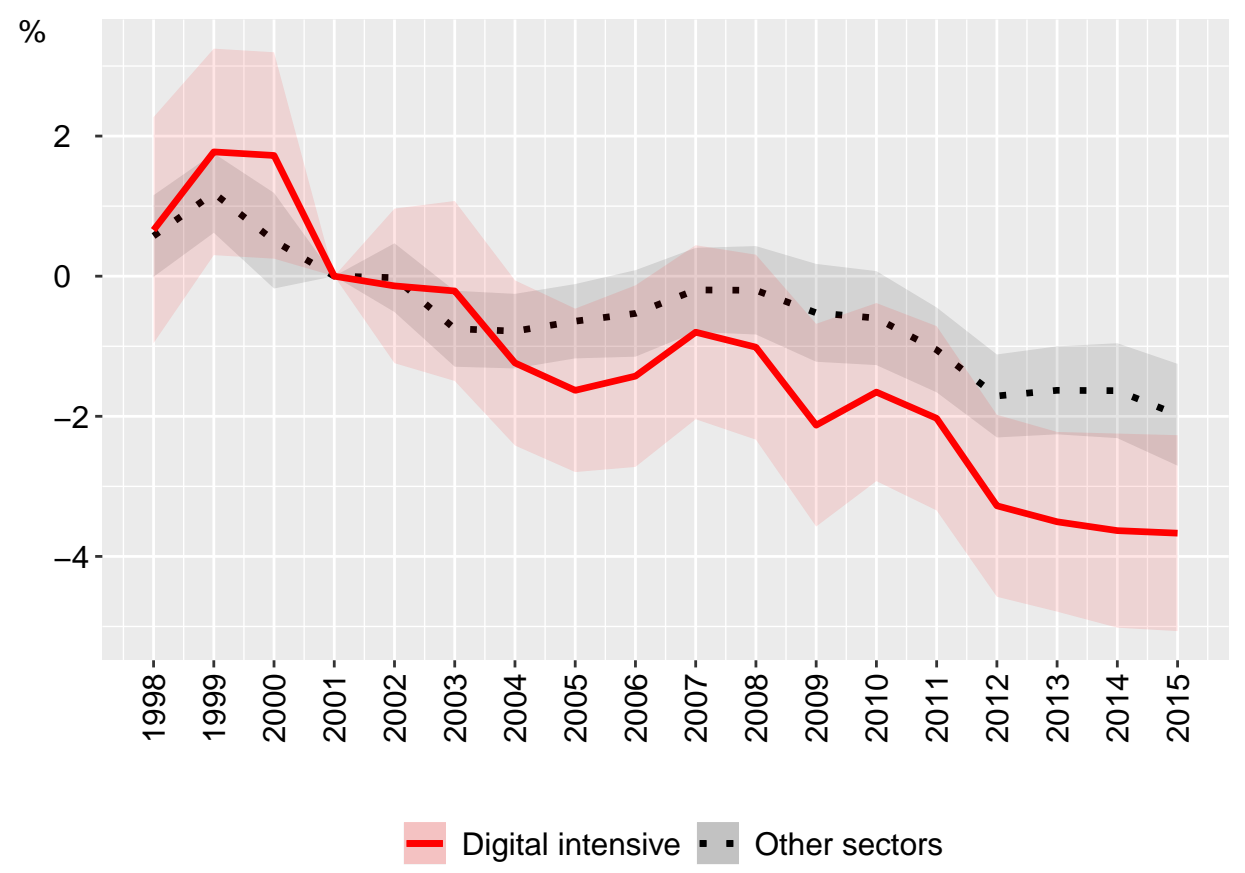




\section{(b) Entry rates}

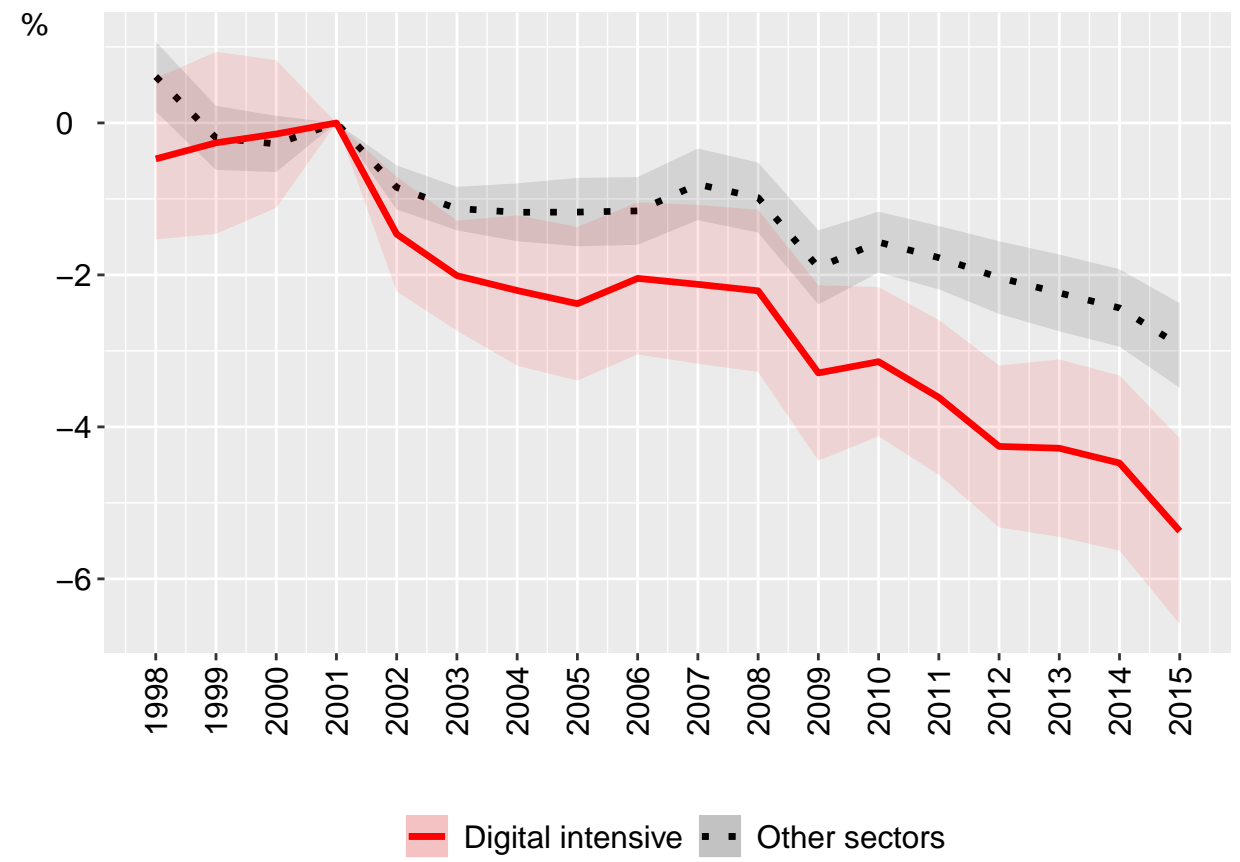

\section{(c) Exit rates}

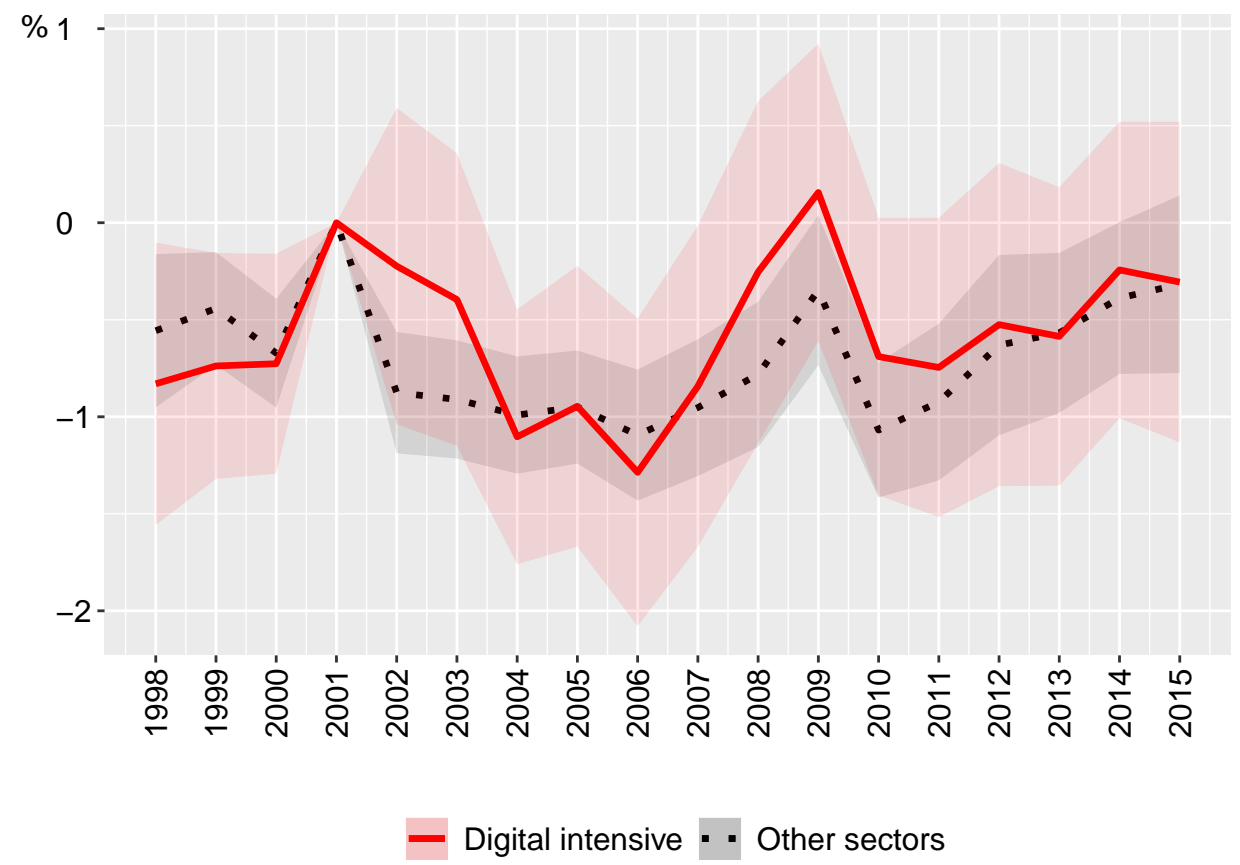

Note: The figures report average within-country-industry trends, based on the year coefficients of regressions within country-sector, with and without interaction with the digital intensity dummy. Digital intensive sectors are reported with a solid line and other sectors with a dashed line. The dependent variables are alternatively job reallocation rates of incumbents, entry rates or exit rates. Confidence bands (95\%) are also reported based on robust standard errors. The baseline year is set to 2001 .

Source: OECD DynEmp3 database, August 2018. 


\subsubsection{These declines appear faster than in other sectors}

Comparing the time trends of digital intensive sectors with those of other sectors suggests that declines in dynamism have been to some extent more pronounced in digital intensive sectors.

This is clear from comparing digital intensive sectors (solid lines) with other sectors (dashed lines) in Figure 4 and while evident for job reallocation rates of incumbents (Panel a), it appears particularly stark for entry rates (Panel b) ${ }^{27}$ while there is no clear-cut trend or cross-sectoral differences in exit rates (Panel c). ${ }^{28}$

These findings are consistent with the US-based evidence on high-tech and information services sectors (see Haltiwanger et al., 2014) as well as with the evidence from Belgium reported in Bijnens and Konings (2018).

\subsubsection{But there are differences across countries}

While the previous stylised facts hold robustly across countries even after controlling for unobserved country(-industry)-specific factors, significant differences across countries are evident.

The panels of Figure 5 report changes in business dynamism in digital intensive sectors between the beginning and the end of the period for each country and highlights significant cross-country variation along all three measures considered. ${ }^{29}$

Panel a and Panel b (Figure 5) focus on job reallocation rates of incumbents and entry rates, respectively. Both point to a generalised decline in this indicators for digital intensive sectors. ${ }^{30}$

The overall stability of exit rates in digital intensive and other sectors discussed in the previous sections is also evident for about half of the countries in the database (Figure 5, Panel c). Other countries rather equally split among those where exit rates in digital intensive sectors increased (Hungary, Italy, Norway, Spain and Sweden) and those where it decreased (Austria, Belgium, France and the Netherlands), but with all rates approximately ranging between $-2 \%$ and $2 \%$.

In additional investigations, not reported here for the sake of brevity, the same analysis is replicated for overall job reallocation rates: the generalised declines in dynamism in digital intensive sectors are qualitatively confirmed. ${ }^{31}$ 
Figure 5. Cross-country differences - Change in business dynamism (digital intensive sectors) (a) Job reallocation rate of incumbents

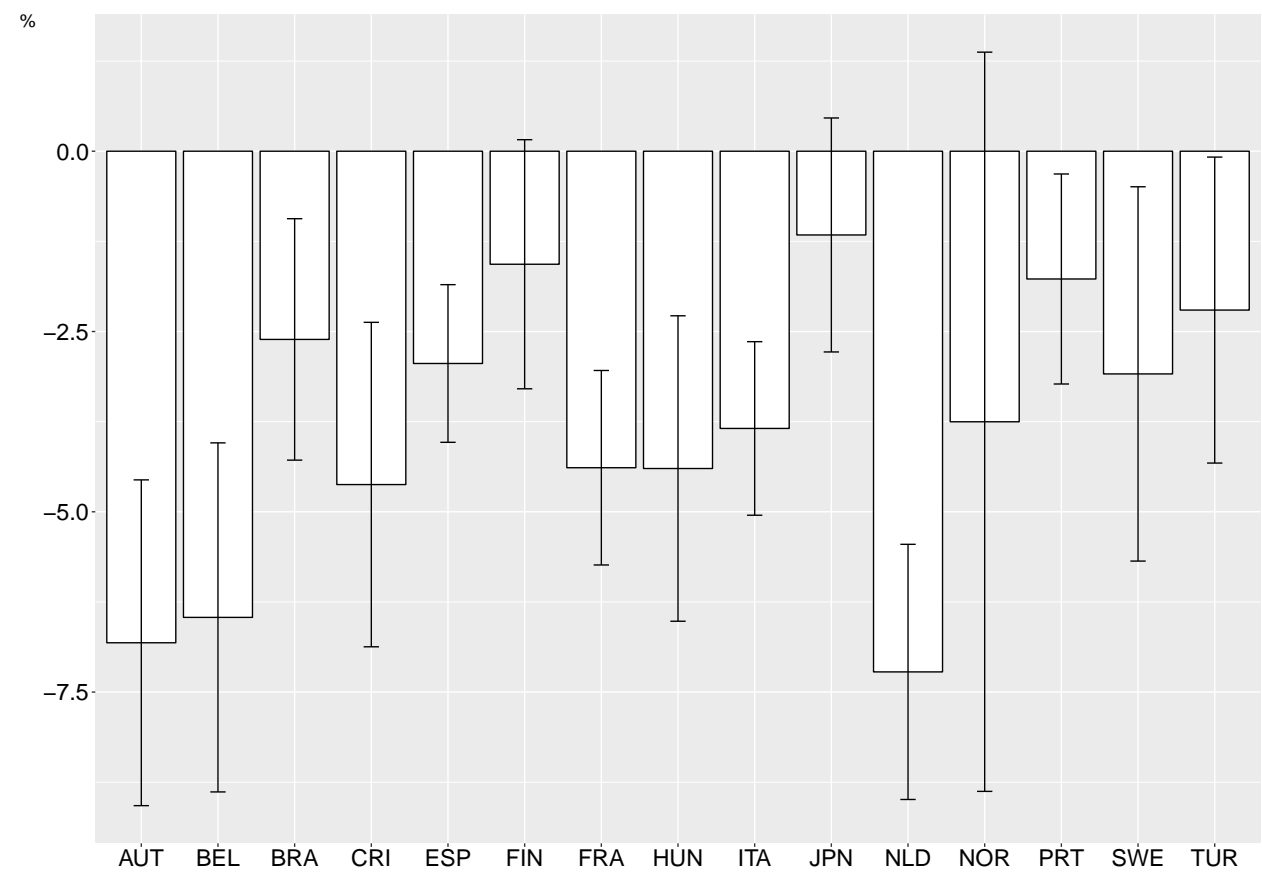

(b) Entry rates

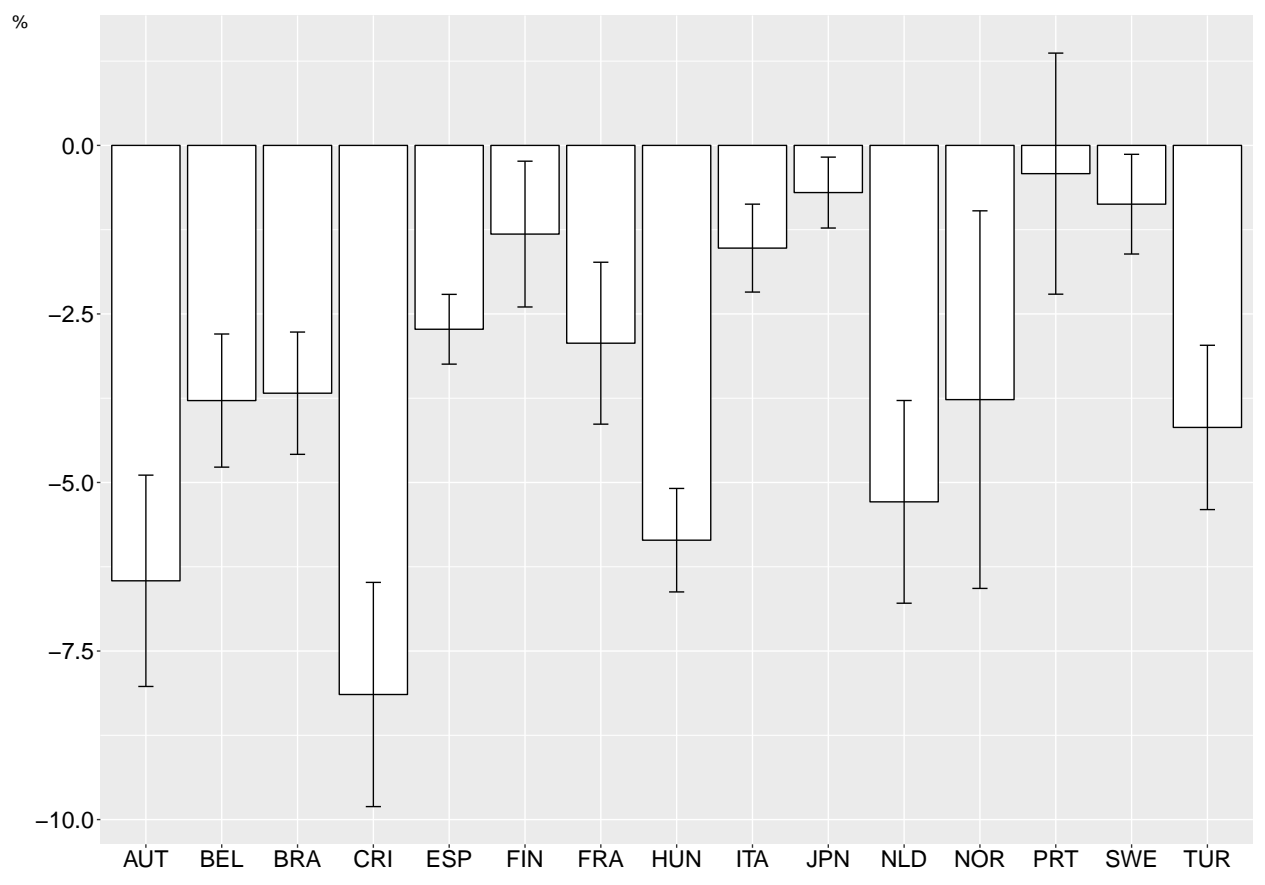




\section{(c) Exit rates}

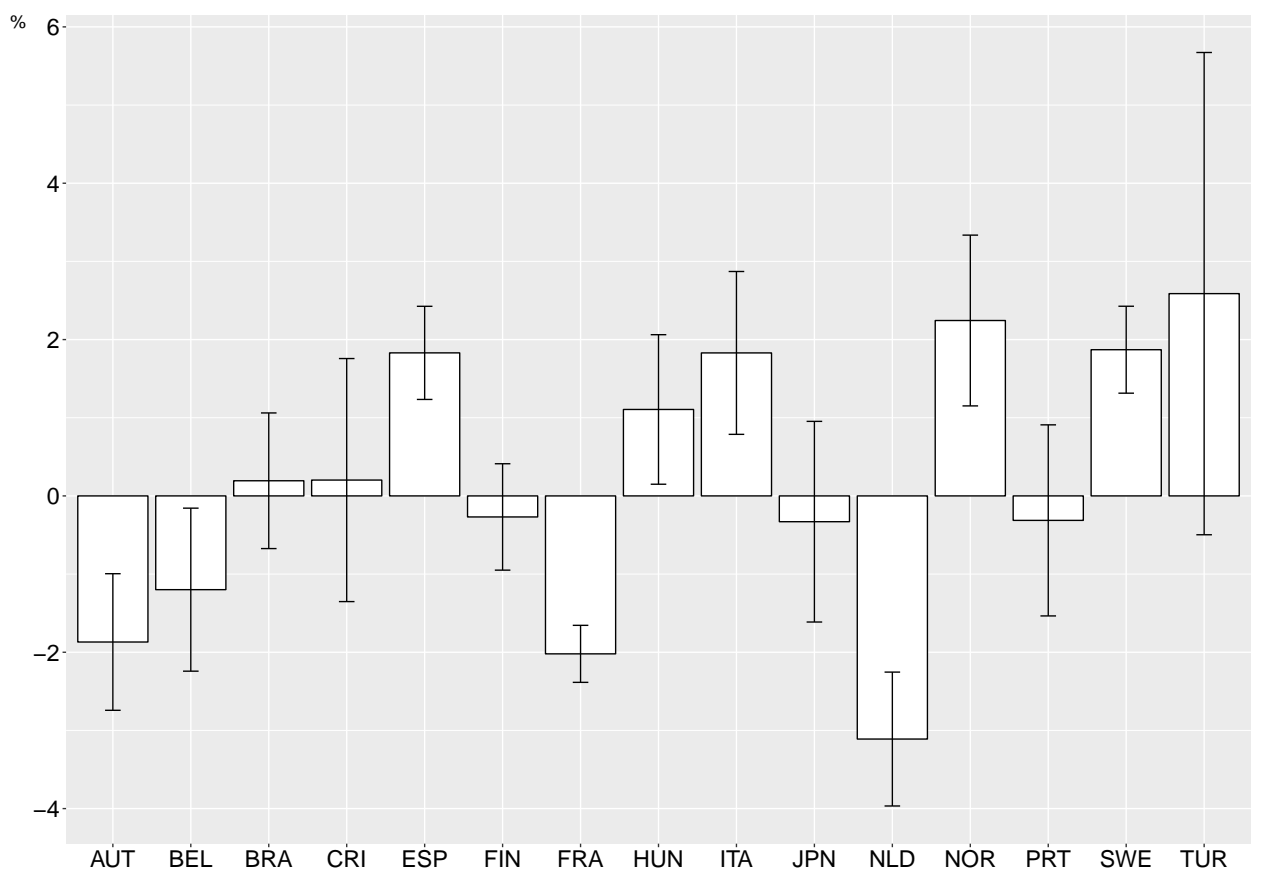

Note: The bars report coefficients based on separate country-specific regressions where the dependent variables are alternatively job reallocation rates of incumbents, entry rates or exit rates, regressed on a dummy equal to 0 in the first 3 years in each countries, and 1 in the last 3 years. Regressions include industry fixed effects and focus on digital intensive sectors. Confidence intervals $(95 \%)$ are also reported based on robust standard errors.

Source: OECD DynEmp3 database, August 2018. 


\section{Potential explanations}

The dynamics highlighted in fact 1 and fact 2 presented in section 4 show features of the digital intensive sectors that are common across countries but also some significant differences. This lead to investigate how much of these findings can be attributed to technology and technological change vis-à-vis country-specific factors.

As a first step, the analysis quantifies the relative importance on technology (industry-specific factors, i.e., technology in a wide sense) and institutional characteristics (country-year-specific factors). This quantification shows that about 35 to $40 \%$ of the variation can be explained by technological change, while about $40 \%$ of the variation seems more related to country-year specific factors. ${ }^{32}$

The rest of the discussion focuses first on the role of technology, and then on the role of policy and institutions and their links with business dynamics in digital intensive sectors.

\subsection{The role of technology}

The first stylised fact highlighted in previous sections is that digital intensive sectors are on average more dynamic with respect to other sectors. This is likely related to the novelty of digital technologies. These technologies have created a number of different and new opportunities for applications and for the development of new business models. Furthermore, digital technologies tend to reduce barriers to entry, facilitate interaction, information flows and access to markets, creating opportunities for experimentation.

Indeed, as emphasised by Goldfarb and Tucker (2017), digital technologies play an important role in reducing costs of search, replication, transportation, tracking, and verification. In particular, lower search costs widen the potential for scope and quality of search, replicability of digital goods often occurs at zero cost (non-rivalry), their cost of transportation is also very low and they enable easier tracking of individual's behaviours, allowing to easily verify the reputation and trustworthiness of information. Thus, this would facilitate entry, upscaling, but also productivity-enhancing creative destruction and a more dynamic business environment.

At first sight, the observed declining dynamism in digitally intensive industries - highlighted by the second stylised fact - may appear at odds with this. However, analysing the evidence taking into account the industry life-cycle and the key characteristics of digital technologies might help reconcile these two facts.

The trends in business dynamics observed in digital intensive sectors seem to reflect quite clearly some of the regularities in the evolution of the industry life-cycle, carefully documented in Klepper (1996) building upon a whole range of evidence, and are intrinsically linked to the general purpose nature of digital technologies (Jovanovic and Rousseau, 2005).

Innovative industries tend to evolve over time according to certain regularities. At the beginning of an industry life-cycle entry is high - may be highest or reach a peak subsequently -, the number of producers grow, market shares change rapidly. Significant product innovations occur, disproportionately accounted by new entrants, with firms offering many competing versions of the industry product (Klepper, 1996).

As the industry evolves, entry declines, there is a shakeout in the number of producers, the industry leadership stabilises, product innovation and the diversity of varieties decline with firms devoting 
increasing efforts to process innovation.

In this framework, the overall dynamics characterising digital intensive sectors presented in this work appear at least broadly consistent with those observed in other innovative industries, for example automobiles, tires, televisions, and penicillin (see Klepper, 2002 and Peltoniemi, 2011).

Indeed, the evidence presented in this paper shows that entry rates peaked in the late 1990s-early 2000s and then declined, while exit rates experienced two key peaks - related to the dot-com bubble and the global financial crisis - and then remained rather stable, with some increases towards the end of the period. Job reallocation rates of incumbents and overall job reallocation have been also declining, and this appears consistent with a shift from higher experimentation and uncertainty to higher stability.

In the framework discussed just above, declines in most recently developed industry- which may have not yet reached their technological maturity - should be faster than the ones experienced by already mature industries. Declines may therefore have been faster in digitally intensive sectors partly due to the different degree of technological maturity of these sectors compared with other sectors in the economy.

In addition, given that the measure of digital intensity used encompasses also the intensity of use of digital technologies, the observed dynamics is clearly shaped by the general purpose nature of these technologies. As discussed by Jovanovic and Rousseau (2005), GPTs enable innovation to spawn beyond sectors producing the GPT. This is likely to open up new opportunities in other sectors (i.e., more entry) and the more so the higher the use. At the same time, these sectors are also likely to be the first ones to follow a similar life-cycle dynamics.

Furthermore, as discussed by Brynjolfsson and McAfee (2012), non-rivalry is an important characteristic of ICTs and information goods. This feature combined with economies of scale and network externalities may have amplified the dynamics typically observed in innovative industries, further contributing to the emergence winner-takes-most markets (Bartelsman, 2013) and possibly increasing the gap between those firms that are able to gain market shares and those that are not (see also Andrews et al., 2016; Brynjolfsson et al., 2007 and Autor et al., 2017), likely because of their endowment in complementary intangible assets (Haskel and Westlake, 2017; Brynjolfsson et al., 2017).

Given the nature of ICTs as general purpose technologies and their input-output linkages, the dynamics generated within the ICT sector may likely diffuse to other sectors of the economy, becoming relevant at the aggregate level. This will be investigated in a separate project that will aim at analysing different structural and policy causes of aggregate trends in business dynamism (Calvino et al., 2018c) together with a focus on the extent to which the types of innovative activities vary over time at different stages of the evolution of sectors. ${ }^{33}$

As a matter of example, anecdotally, one can think about some of the leading internet platforms or internet-based services. The interpretation proposed would suggest that at the beginning of the industry, many competing services are proposed. Over time, some services gain market shares and customers, while others do not reach scale. As time goes by this is amplified by network externalities typical of these sector and some services get significant mass, possibly becoming leaders. At the same time, innovation spawns to other related sectors that can take advantage of new opportunities for applications.

As the industry evolves, instead of competing on new services, the focus of innovation efforts shifts to the efficiency with which these digital services are provided. While new entrants were more likely to bring radical innovation into the market, this stage seems more related to incremental 
competence-enhancing change (Tushman and Anderson, 1986).

Despite there being different hypotheses about the role of artificial intelligence and machine learning and whether they are spurring a new paradigmatic shift, one may think of some of these applications as a shift to process innovation, bringing improvements in the way in which services are delivered, information is organised and elaborated. Indeed, Furman and Seamans (2018) have documented significant rising trends in AI patenting and robotics that may be consistent with a change in the patterns of innovative activities in digital intensive sectors, with potential implications for future developments of business dynamics in these sectors.

\subsubsection{Consistency with other empirical findings}

The observed dynamics presented in this paper and their proposed interpretation appear in line with a number of other trends that have been documented by the literature.

As already emphasised, the figures presented for digital intensive sectors are consistent with the US-based evidence on high-tech and information services sectors (see Haltiwanger et al., 2014), where increases in dynamism are evident in the late 1990s until the beginning of the 2000s, followed by prominent declines. Also these sectors exhibit highest job reallocation levels since the 1990s. The dynamics presented are also very much consistent with the country-specific evidence on growth dispersion and skewness in Belgium reported by Bijnens and Konings (2018), suggestive of stronger declines in ICT sectors.

The observed trends in business dynamism are in line with the evidence on rising mark-ups in digital intensive sectors (Calligaris et al., 2018) and with the evidence of rising concentration and increasing mergers and acquisitions (M\&A) activities in the same sectors (see Bajgar et al., 2018). This seems to suggest that the observed dynamics may be all the outcome of common factors linked to the evolution of digital technologies.

The findings are also consistent with the evidence on winner-takes-most dynamics in ICT intensive sectors discussed by Andrews et al. (2016), to the extent that these divergences may reflect technological and institutional barriers to entry, and on the emerging literature on superstar firms (Autor et al., 2017). 


\subsection{The role of policy}

Motivated by the significant differences across countries, this section presents a guiding framework for policy-makers and analyses the role of institutions and policy in explaining the observed dynamics.

The policy analysis focuses on entry rates as a key outcome variable, since this is the measure that exhibits both the highest average variation over time and the most considerable cross-country heterogeneity in levels among the three business dynamism measures examined in this work.

Moreover, focusing on entry is particularly consistent with previous OECD analysis that highlights how entrants are disproportionately affected by institutions and policy reforms with respect to incumbent firms, especially in more risky or volatile sectors (Calvino et al., 2016).

\subsubsection{A guiding framework for policy-makers}

In this context, a guiding framework for the policy analysis is presented in Figure 6. It discusses six important drivers of entry rates, together with the relevant policy levers at disposal of policy-makers.

Entry rates are related to the supply (quantity) and quality of entrepreneurs in a country. In this context, human capital, education - in terms of educational attainment but also of quality of the education system -, and training of workers play an important role and policy-makers can influence these outcomes with appropriate policy instruments. Availability of capital, especially seed and early stage financing but also to some extent bank loans, is crucial as it enables these potential entrepreneurs with the financial means needed to start their venture.

In order to enter the market, potential entrepreneurs enabled with financial means need to be motivated by the expected return of their project, and this is linked with the possibility of successfully listing their company on the stock markets. But they also need to be able to set up their business easily, thanks to low regulatory entry barriers and low administrative burdens.

Once entry has occurred, new firms need to face a level playing field and get equal opportunities with respect to other incumbent firms. Important levers in this context are related to business regulations, efficiency in the enforcement of contracts and innovation support measures. Finally, entrepreneurs need to be able to experiment as this is a key feature of the creative destruction process. Policy related to the cost of reallocation (such as employment protection legislation) and to cost of failure (efficiency of bankruptcy regulation) are important levers that policy-makers can influence.

A significant number of country-specific proxies of the drivers mentioned above is used for the policy analysis, sourcing these variables from the OECD Structural Policy Indicators Database for Economic Research (SPIDER), complemented with data from the OECD Indicators of Employment Protection. ${ }^{34}$ 
Figure 6. Entry rates: drivers and policy levers

POLICY LEVERS

DRIVERS

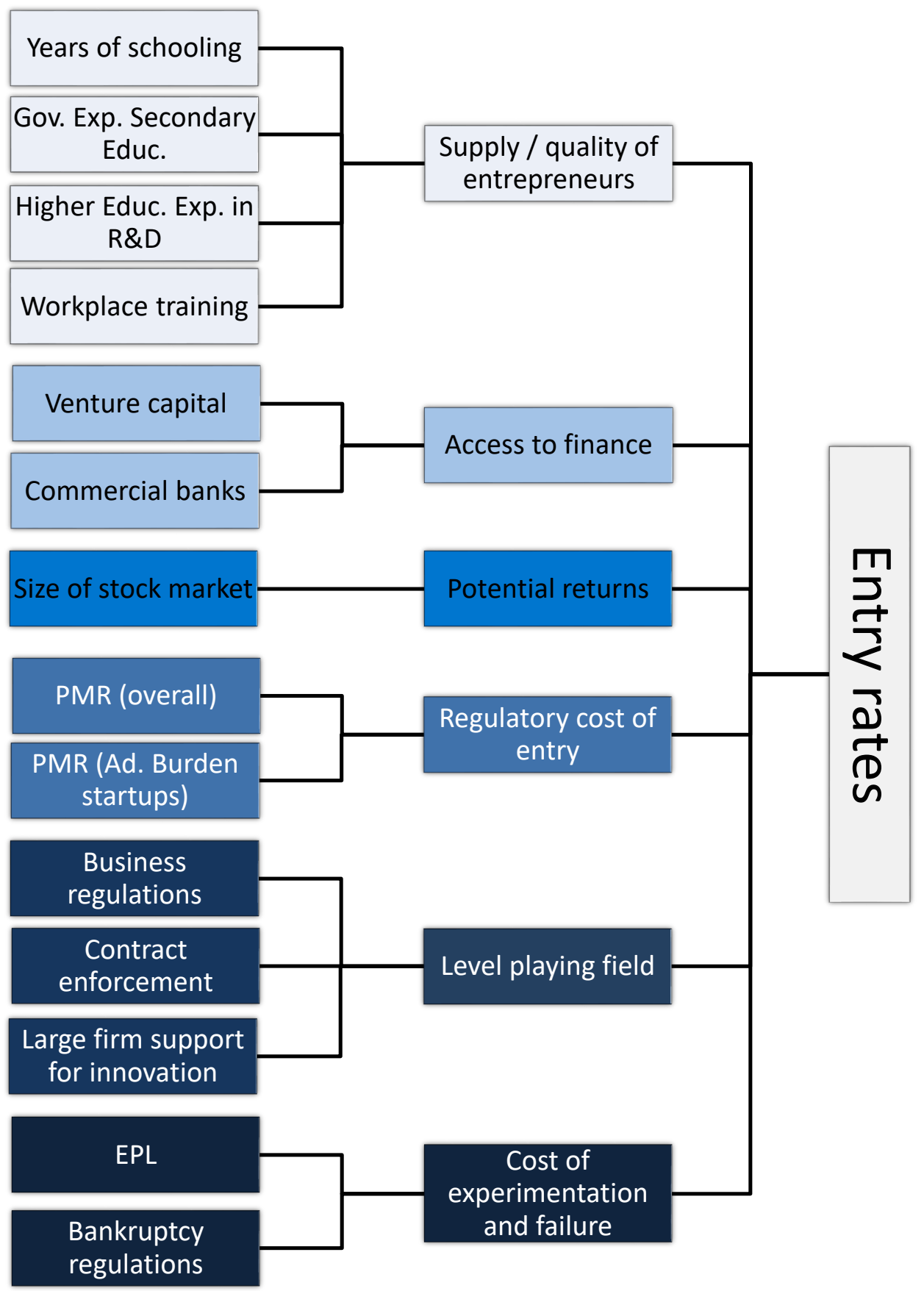


These variables include measures related to education (years of schooling, government expenditures per student (secondary education), higher education expenditures on R\&D), workplace training, indicators of venture capital availability and presence of commercial bank branches, product market regulations (both related to overall competition in product markets and with a particular focus on administrative burdens for start-ups), stock traded in the market as a share of GDP, indicators of the time needed to enforce contracts, of the efficiency of the overall business regulatory environment and of innovation support for large firms, measures of the stringency of employment protection legislation and of the efficiency of bankruptcy procedures.

A detailed summary of these variables is presented in the Appendix (Table A8), restricting the focus to the 1998-2015 period as this is the time horizon under investigation. ${ }^{35}$ A table of descriptive statistics (before standardisation) is presented in the Appendix (Table A9). Additional details about their construction are available in Égert et al. (2017).

\subsubsection{Methodology and key findings}

The main approach used to estimate the extent to which policy and institutional factors influence business dynamism in digital intensive sectors follows the methodology proposed by Rajan and Zingales (1998). In particular, the basic intuition of this approach is that some sectors may be more exposed than others to the effect of certain national policies or framework conditions due to some of their (technological or structural) characteristics. The identification of the impact of policies is therefore based on this differential exposure of sectors to policy.

In this context, the approach is adapted using as exposure variable the same digital intensity measure used in the rest of this paper. This allows to assess the extent to which different policies have a differential role for business dynamics mediated by digital intensity. The main model estimated becomes therefore the following:

$$
\text { EntryRate }_{c, s, t}=\beta \times \text { Policy }_{c, t} \times \text { Digital }_{s}+\kappa_{c} \times \theta_{t}+\gamma_{s}+\varepsilon_{c, s, t}
$$

where EntryRate identifies the log of entry rates, Policy refers alternatively to each of the policy variables described above, Digital is the digital intensity indicator used in the rest of the paper; ${ }^{36}$ subscript $c$ indicates countries, $t$ year, and $s$ sectors.

A summary of the results is presented in Figure 7 below (and in Table A10 in the Appendix). ${ }^{37}$ A positive (negative) coefficient is to be interpreted as an indication of the fact that the particular policy under investigation is positively (negatively) related to entry rates in digital intensive sectors. In other words, an improvement along the particular policy setting examined are estimated to have a positive (negative) association with business dynamism in these sectors.

The results highlight the relevance for digital intensive sectors of the six drivers of entry rates discussed in the guiding policy framework.

First, education ${ }^{38}$ and workplace training, as related to the supply and quality of entrepreneurs especially in a rapidly changing environment, are particularly important for entry rates in digital intensive sectors. The role of training might appear surprising at first, but is likely reflecting that in sectors with high level of dynamism, the stock of entrepreneurs might not only come from inexperienced young founders, but also from workers which might have received training before. 
Second, facilitating access to finance for new firms, particularly in terms of venture capital availability at seed and early stages, is an important lever for entrepreneurship in digital intensive sectors vis-à-vis less digital intensive ones. Indeed this enables digital entrepreneurs with the financial means needed to start their company, which is particularly important for high-tech high-potential ventures. Conversely, the presence of commercial banks does not seem to play an important role for entry in digital intensive sectors, despite this may be more relevant for later stages in the firm life, or simply more broadly relevant in all sectors of the economy.

Third, considerable potential returns to entrepreneurship confirm to be important drivers of entry, especially in digital intensive sectors where the potential for scaling-up and going public appear as important motivations to start a company. Indeed, the size of the stock market which is used as proxy for these potential returns is positively associated with entry rates, particularly in digital intensive sectors.

Fourth, the results highlight the importance of reducing regulatory barriers, especially those related to administrative burdens for start-ups, which may include the number of procedures, their length, and the cost needed to register a new company. This appears particularly relevant in digital intensive sectors where the fast pace of technological change and the more and more global competitive environment require particularly intuitive and short procedures for new firms to register.

Relatedly, assuring a level playing field, such as efficient contract enforcement and more in general efficient business regulations, confirms to be important framework conditions to ensure creative destruction and dynamism. Interestingly, considerable innovation support for large firms (in terms of R\&D tax generosity) seems to be negatively associated with entry rates in digital intensive sectors, possibly suggesting some caution in the design of innovation policies.

Finally, avoiding excessive costs of experimentation and failure, and in particular inefficient bankruptcy procedures, is particularly beneficial for entry in digital intensive sectors, which tend to be the sectors where reallocation needs and riskiness are higher. ${ }^{39}$

An extensive number of exercises have been carried out to test the robustness of the findings presented in Figure 7. These are discussed more in detail in the Appendix, and overall they qualitatively confirm the main results presented.

More ambitiously, additional analysis has focused specifically on digital intensive sectors investigating the correlation between long-time changes in policy factors and long-time changes in business dynamism. ${ }^{40}$ Reassuringly, this analysis qualitatively confirms the main overall results. ${ }^{41}$ 


\section{Figure 7. Policy regressions results}

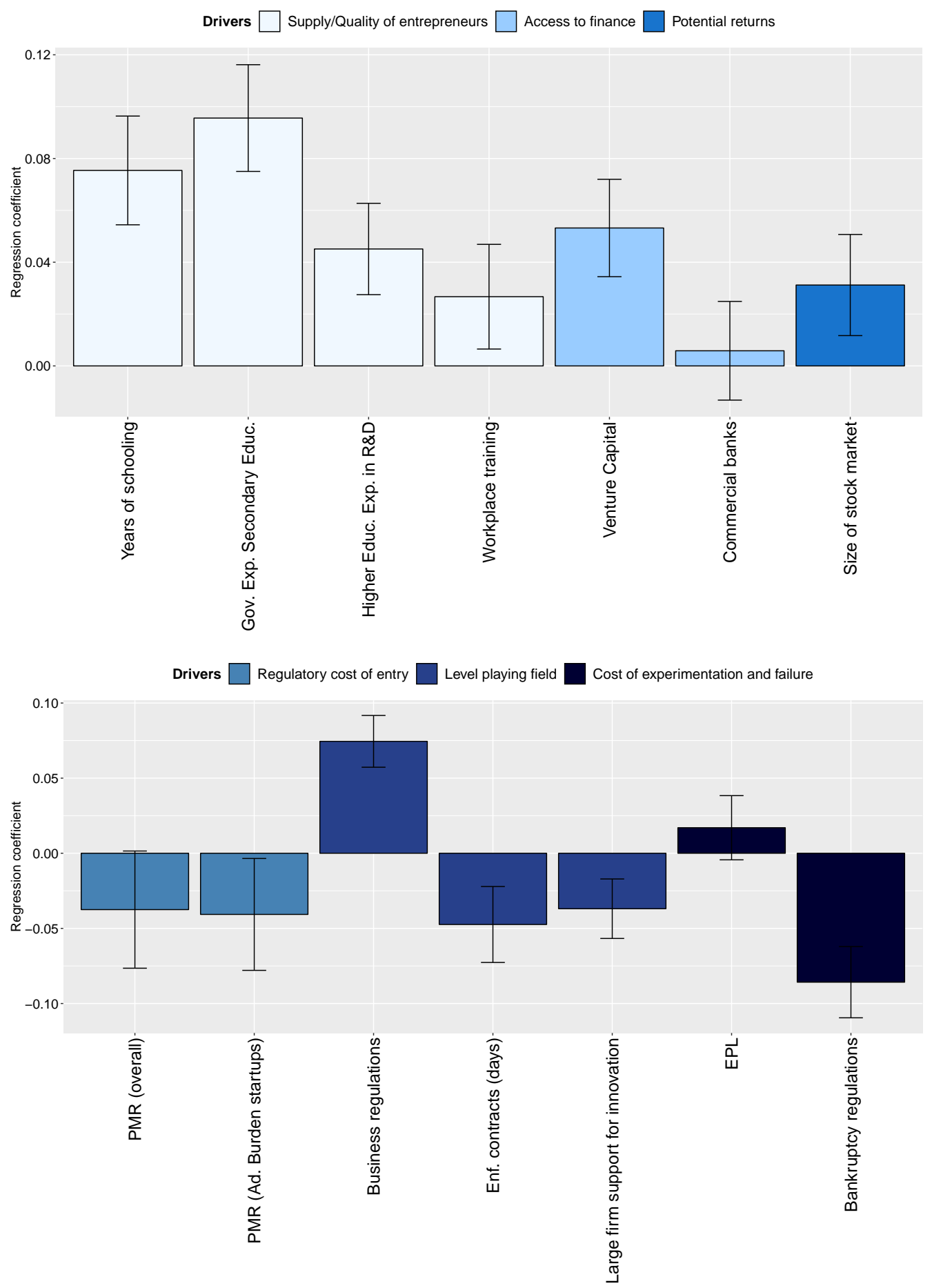

Note: The bars report coefficients based on separate regressions where the dependent variable is (the log of) entry rates, the exposure variable is the digital intensity dummy and the policy variables are those listed in the text (see Equation 1). All regressions include country-year and sector fixed effects. Confidence intervals $(95 \%)$ are also reported based on robust standard errors.

Source: OECD DynEmp3 database, August 2018; OECD SPIDER database; OECD EPL Indicators. 


\subsubsection{An illustration using possible policy reforms}

So far, the discussion has focused on the sign and the significance of the coefficients of the policy regressions. Related questions are how the magnitude of these coefficients presented in Figure 7 can be interpreted and whether these have economically sizeable implications. One way to address these questions is to carry out a "reform simulation" exercise. This consists in using the estimated coefficients to calculate the impact on the dependent variables of a hypothetical policy reform, which would shift the value of a policy indicator in a given country from its current actual value to, for instance, the top (most business-friendly) value in the sample under scrutiny. ${ }^{42}$

\section{Figure 8. Reform simulation example - Entry rates}

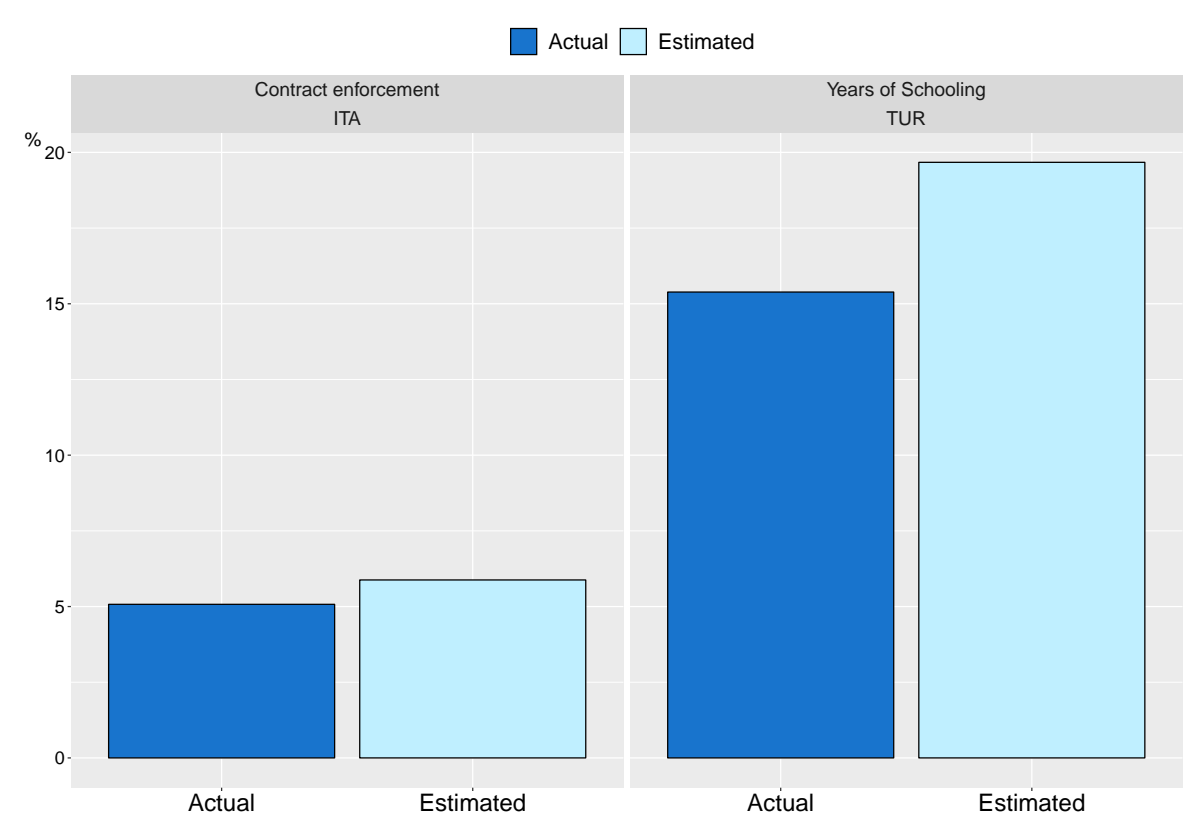

Note: The bars report the estimated effects on entry rates in digital intensive sectors of two hypothetical reforms, if the regression coefficients were to be interpreted causally. Details are described in the main body of text. Descriptive statistics of the policy variables are reported in Table A9 in the Appendix. The results of these reform simulation examples are just suggestive.

Source: estimates based on the OECD DynEmp3 database and OECD SPIDER database.

For example, as illustrated in Figure 8, if the days necessary to resolve a commercial dispute (contract enforcement) in Italy were to drop from about 3 years to less than one year, i.e. the time needed in Norway, estimates would suggest an average increase of entry rates in digital intensive sectors of about 1 percentage point. Similarly, if in Turkey average years of schooling were to reach the levels observed in Japan (which corresponds to a shift from about 7 to about 13), the estimates suggest that this would be linked with an average increase of entry rates in digital intensive sectors of about 4 percentage points.

The results of these reform simulation examples are just suggestive and should not be interpreted literally, as they are based on a number of strong and sometimes unrealistic assumptions. They are meant to just provide an indication about the magnitude of the regression coefficients, if they were to be interpreted causally. 


\section{Some conclusions}

This work has analysed the role of the digital transformation for business dynamics across countries. The analysis has combined unique harmonised data on business dynamics for 15 countries with a multi-dimensional measure of digital intensity that takes into account different facets of the digital transformation. Two key stylised facts emerged

First, digital intensive sectors - especially digital intensive services - are on average more dynamic than other sectors of the economy, exhibiting higher entry rates and higher job reallocation rates. This is consistent with the idea that digital technologies lower entry barriers and tend to facilitate reallocation.

Second, business dynamism has been declining in digital intensive sectors, especially after 2001 . Interestingly, this decline appears to some extent faster than the one occurring in other sectors of the economy, possibly due to the relative novelty of ICTs. Indeed, these patterns appears linked to technology and has characterised a number of innovative industries in the past but, in this particular case, may have been further boosted by network externalities and the general purpose nature of digital technologies.

The robustness of the presented patterns suggests that they are - at least to some extent - related to specific characteristics of digital technologies. Indeed, the analysis reveals that about 35 to $40 \%$ of the variation in entry rates is related to technological change. Still, given that variation across countries might account for a similar share of the patterns observed, the role of policy and institutions is analysed.

In this context, econometric analysis carried out in the framework of Rajan and Zingales (1998) has suggested the importance for business dynamism in digital intensive sectors of i) promoting education and training, as related to the supply and quality of entrepreneurs, especially in a rapidly changing environment; ii) facilitating access to finance for new ventures, particularly venture capital at seed and early stages; iii) stimulating potential returns to entrepreneurship; iv) reducing regulatory barriers to entry and administrative burdens for start-ups; v) assuring a level playing field, such as efficient contract enforcement and business regulations; vi) avoiding excessive costs of experimentation and failure, and in particular inefficient bankruptcy procedures.

Ongoing OECD work is analysing the pervasiveness of the declines in business dynamism across countries and their causes, including globalisation, demography, regulations, technology and macro-economic factors (Calvino et al., 2018c). In this context, given the nature of ICTs as general purpose technologies and their input-output linkages, this work will investigate empirically the extent to which the dynamics generated within the ICT sector may have influenced trends in other sectors of the economy, becoming relevant at aggregate level.

Further work on post-entry growth in digital intensive sectors and the extent to which employment growth trends relate (or not) to turnover growth dynamics, and how this differs across sectors and over time, appears also as a promising avenue for future research, in the context of the debate about scaling without mass (see Brynjolfsson et al., 2007). ${ }^{43}$ 


\section{Appendix}

\section{Methodology and main variables definition}

This Appendix provides the main definitions of the DynEmp3 data used in this work.

\section{Dimensions of analysis}

Unit $(i)$ : The main unit of analysis in the DynEmp data collection is the firm (as reported in the text, for few countries the unit of analysis is the establishment).

Cell $(c)$ : The measures collected in the DynEmp database are computed at different breakdowns. These breakdowns include: age class, size class, industry, country. These dimensions allow to define cells at different levels of aggregation (e.g., countr $y \times$ industry; country $\times$ industr $y \times$ size, country $\times$ industry $\times$ age, etc.). More details on age classes, size classes and on the industry classification are available upon request.

Time $(t)$ : Each cell is computed at different points in time. The time reference unit is the year. Measures are computed yearly taking advantage of the underlying longitudinal structure of input microdata.

Accordingly $X_{c, t}$ denotes the value of variable $\mathrm{X}$ for cell $c$ at time $t$. For instance $I_{c, t}$ is the number of firms in cell $c$ at time $t$.

Status: Within each cell, the DynEmp database separates units of different status (entering units, incumbent units or exiting units). While the status of the unit could enter the definition of a cell, we generally consider it as a partition within the cell.

- Entering unit: a unit is an entrant in $t$ if it is not present in the micro data in year $t-1$ but is present in $t$ with positive employment. ${ }^{44}$

- Exiting unit: a unit is an exit in $t$ if it is not present in $t$ and is there in $t-1$ with positive employment.

- Incumbent unit: an incumbent unit is present both in $t-1$ and in $t$.

We denote by $X c, t^{s u b}$ the value of variable $\mathrm{X}$ for a partition of a cell $c$ at time $t$. For instance $I_{c, t}^{\text {entry }}$ is the number of entrants in cell $c$ at time $t$.

$X^{\text {incb }}$ refers instead to variable $X$ computed for the group of incumbents only. This implies using only incumbents for all the varibles entering the definition of $X$. Thus, if $X=\frac{U}{Y+Z}$, then $X^{\text {incb }}=\frac{U^{\text {incb }}}{Y^{\text {incb }}+Z^{\text {incb }}}$.

\section{Main variables definition}

Number of units (I) : Total number of units $i$ (having at least one person engaged) in a cell $c$ at timt $t$. 
Total employment (E) : The sum of employment across all units $i$ in a cell $c$.

$$
E_{c, t}=\sum_{i \in c} E_{i, t}
$$

Gross Job Creation (JC) : Sum of all positive unit-level job variations between t-1 and t in cell $c$ :

$$
J C_{c, t}=\sum_{i \in c} \Delta^{+} E_{i, t}
$$

whith $\Delta^{+} E_{i, t}=1_{\left(E_{i, t}-E_{i, t-1}\right)>0} \cdot\left(E_{i, t}-E_{i, t-1}\right)$, where $1_{\left(E_{i, t}-E_{i, t-1}\right)>0}$ is a dummy variable equal to one when the firm level change in employment is positive, and 0 otherwise.

Gross Job Destruction (JD): Absolute value of the sum of all negative unit-level job variations between $\mathrm{t}-1$ and $\mathrm{t}$ in cell $c$ :

$$
J D_{c, t}=\left|\sum_{i \in c} \Delta^{-} E_{i, t}\right|
$$

whith $\Delta^{-} E_{i, t}=1_{\left(E_{i, t}-E_{i, t-1}\right)<0} \cdot\left(E_{i, t}-E_{i, t-1}\right)$, where $1_{\left(E_{i, t}-E_{i, t-1}\right)<0}$ is a dummy variable equal to one when the firm level change in employment is negative, and 0 otherwise.

Job creation rate (JCR): Ratio of gross job creation over average employment in the 2-years period, times 100:

$$
J C R_{c, t}=\frac{J C_{c, t}}{\frac{1}{2}\left(E_{c, t}+E_{c, t-1}\right)} \times 100
$$

Job destruction rate (JDR): Ratio of gross job destruction over average employment in the 2-years period, times 100:

$$
J D R_{c, t}=\frac{J D_{c, t}}{\frac{1}{2}\left(E_{c, t}+E_{c, t-1}\right)} \times 100
$$

Job reallocation rate: job creation in cell $c$ plus job destruction in the cell, over average of total employment in the cell in period $t$ and total employment in period $t-1$.

$$
\text { JobReallRate }_{c, t}=\frac{J C_{c, t}+J D_{c, t}}{\frac{1}{2}\left(E_{c, t}+E_{c, t-1}\right)} \times 100
$$


Job reallocation rate of incumbents: job reallocation rate rate focusing on incumbent units only.

$$
\text { JobReallRate }_{c, t}^{i n c b}=\frac{J C_{c, t}^{i n c b}+J D_{c, t}^{i n c b}}{\frac{1}{2}\left(E_{c, t}^{i n c b}+E_{c, t-1}^{i n c b}\right)} \times 100
$$

Entry rate: Number of entering units in cell $c$ over number of entering and incumbent units in cell $c$.

$$
\text { EntryRate }_{c, t}=\frac{I_{c, t}^{e n t}}{I_{c, t}^{\text {incb }}+I_{c, t}^{\text {ent }}}
$$

Exit rate: Number of exiting units in cell $c$ over number of exiting and incumbent units in cell $c$.

$$
\text { ExtRate }_{c, t}=\frac{I_{c, t}^{\text {ext }}}{I_{c, t}^{i n c b}+I_{c, t}^{e x t}}
$$

Outliers in the key outcome variables used for the descriptive and econometric analysis - calculated within country-sector exploiting the time variation and defined following Tukey (1977) - are replaced to missing to make sure that results are not driven by unusual jumps. 
Additional graphs and tables

Table A1. Contributors to the DynEmp project

\begin{tabular}{l|cc}
\hline Country & National representative & Institution \\
\hline \hline Austria & Werner Hölzl & WIFO - Austrian Institute of Economic Research \\
Belgium & Michel Dumont, Chantal Kegels & Federal Planning Bureau \\
Brazil & Carlos Henrique Leite Corseuil & Instituto de Pesquisa Economica Aplicada (IPEA) \\
Costa Rica & Cristian Álvarez Corrales & Central Bank of Costa Rica \\
Finland & Mika Maliranta & The Research Institute of the Finnish Economy (ETLA) \\
France & DynEmp and MultiProd team & OECD \\
Hungary & Mihály Szoboszlai & Central Bank of Hungary \\
Italy & Stefano Costa & ISTAT \\
Japan & Kenta Ikeuchi & Research Institute of Economy, Trade and Industry (RIETI) \\
Netherlands & Michael Polder & Statistics Netherlands \\
Norway & Arvid Raknerud, Diana-Cristina Iancu & Statistics Norway \\
Portugal & Paulo Dias & Min. of Labour, Solidarity, and Social Security (GEP) \\
Spain & Valentin Llorente Garcia & Spanish Statistical Office (INE) \\
Sweden & Fredrik Andersson & Statistics Sweden \\
Turkey & Faik Yücel Günaydn & Min. of Science, Industry and Technology \\
\hline
\end{tabular}

Table A2. Data sources

\begin{tabular}{l|c}
\hline Country & National data source \\
\hline \hline & WIFO INDI DV (Social Security data) \\
Austria & Belgium \\
Brazil & National Social Security Office; BR; Central Balance Sheet Office (NBB) \\
Costa Rica & Annual Social Information Report (RAIS) \\
Finland & Registro de variables economicas-REVEC (database from BCCR) \\
France & Business Register on Companies; Survey extended with tax register information \\
Hungary & FICUS up to 2007, FARE from 2008 \\
Italy & Corporate Income Tax data (CIT) of National Tax and Custom Administration \\
Japan & ASIA (BR) + Frame SBS from 2011 onward \\
Netherlands & Census of Manufactures \\
Norway & Business Register; FATS; Fiscal Register \\
Portugal & Business Register; Fiscal or tax Register \\
Spain & Relatório Único / Quadros de Pessoal (BR) \\
Sweden & Business Register \\
Turkey & RAMS (Statistics Sweden's Register-based labour market statistics) \\
\hline
\end{tabular}


Table A3. Coverage of the DynEmp3 database by country over time

\begin{tabular}{|c|c|c|c|c|c|c|c|c|c|c|c|c|c|c|c|c|c|c|c|c|c|c|}
\hline & @ & $\hat{8}$ & $\hat{\Omega}$ & 108 & ह & & & હ઼ & 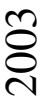 & 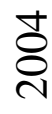 & $\stackrel{n}{8}$ & ๖్రి & 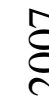 & & & & $\frac{0}{\grave{d}}$ & ల్ల & $\frac{\sim}{\stackrel{\sim}{N}}$ & & ন & $\stackrel{n}{\frac{n}{2}}$ \\
\hline Austria & & & & & & & & & & & & & & & & & & & & & & \\
\hline BELGIUM & & & & & & & & & & & & & & & & & & & & & & \\
\hline BRAZIL & & & & & & & & & & & & & & & & & & & & & & \\
\hline Costa R & & & & & & & & & & & & & & & & & & & & & & \\
\hline FINLAND & & & & & & & & & & & & & & & & & & & & & & \\
\hline FRANCE & & & & & & & & & & & & & & & & & & & & & & \\
\hline HUNGAR & & & & & & & & & & & & & & & & & & & & & & \\
\hline ITALY & & & & & & & & & & & & & & & & & & & & & & \\
\hline JAPAN & & & & & & & & & & & & & & & & & & & & & & \\
\hline THE NET & & & & & & & & & & & & & & & & & & & & & & \\
\hline NoRWAY & & & & & & & & & & & & & & & & & & & & & & \\
\hline Portuga & & & & & & & & & & & & & & & & & & & & & & \\
\hline SPAIN & & & & & & & & & & & & & & & & & & & & & & \\
\hline SWEDEN & & & & & & & & & & & & & & & & & & & & & & \\
\hline TURKEY & & & & & & & & & & & & & & & & & & & & & & \\
\hline
\end{tabular}

Note: Temporal coverage by country of current version of the DynEmp3 database. Years 1996 and 1997 are excluded from the analysis due to limited cross-country coverage. Grey boxes correspond to years that have been excluded from the analysis due to ongoing checks on the output or substantial changes in the series. Data for some countries are still preliminary. 
Table A4. Industry classification table

\begin{tabular}{|c|c|c|}
\hline \multicolumn{2}{|r|}{ STAN A38 based on ISIC v.4 classification } & \multirow{2}{*}{$\begin{array}{l}\text { STAN A7 } \\
\text { Agriculture }\end{array}$} \\
\hline 01 to 03 & Agriculture, forestry and fishing & \\
\hline 05 to 09 & Mining and quarrying & Mining \\
\hline 10 to 12 & Food products, beverages and tobacco & \multirow[t]{13}{*}{ Manufacturing } \\
\hline 13 to 15 & $\begin{array}{l}\text { Textiles, wearing apparel, leather and related } \\
\text { products }\end{array}$ & \\
\hline 16 to 18 & Wood and paper products, and printing & \\
\hline 19 & Coke and refined petroleum products & \\
\hline 20 & Chemicals and chemical products & \\
\hline 21 & $\begin{array}{l}\text { Basic pharmaceutical products and } \\
\text { pharmaceutical preparations }\end{array}$ & \\
\hline 22 to 23 & $\begin{array}{l}\text { Rubber and plastics products, and other } \\
\text { non-metallic mineral products }\end{array}$ & \\
\hline 24 to 25 & $\begin{array}{l}\text { Basic metals and fabricated metal products, } \\
\text { except machinery and equipment }\end{array}$ & \\
\hline 26 & Computer, electronic and optical products & \\
\hline 27 & Electrical equipment & \\
\hline 28 & Machinery and equipment n.e.c. & \\
\hline 29 to 30 & Transport equipment & \\
\hline 31 to 33 & $\begin{array}{l}\text { Furniture; other manufacturing; repair and } \\
\text { installation of machinery and equipment }\end{array}$ & \\
\hline 35 & $\begin{array}{l}\text { Electricity, gas, steam and air conditioning } \\
\text { supply }\end{array}$ & \multirow[t]{2}{*}{ Utilities } \\
\hline 36 to 39 & $\begin{array}{l}\text { Water supply; sewerage, waste management } \\
\text { and remediation activities }\end{array}$ & \\
\hline 41 to 43 & Construction & Construction \\
\hline
\end{tabular}




\section{(continued)}

\begin{tabular}{|c|c|c|}
\hline 45 to 47 & $\begin{array}{l}\text { Wholesale and retail trade, repair of motor } \\
\text { ve hicles and motorcycles }\end{array}$ & Market services \\
\hline 49 to 53 & Transportation and storage & \\
\hline 55 to 56 & Accommodation and food service activities & \\
\hline 58 to 60 & $\begin{array}{l}\text { Publishing, audiovisual and broadcasting } \\
\text { activities }\end{array}$ & \\
\hline 61 & Telecommunications & \\
\hline 62 to 63 & IT and other information service & \\
\hline 64 to 66 & Financial and Insurance activities & Excluded \\
\hline 68 & Real Estate activities & Market services \\
\hline 69 to 71 & $\begin{array}{l}\text { Legal and accounting activities; activities } \\
\text { of head offices; management consultancy } \\
\text { activities; architecture and engineering } \\
\text { activities; technical testing and analysis }\end{array}$ & \\
\hline 72 & Scientific research and development & \\
\hline 73 to 75 & $\begin{array}{l}\text { Advertising and market research; other } \\
\text { professional, scientific and technical } \\
\text { activities; veterinary activities }\end{array}$ & \\
\hline 77 to 82 & Administrative and support service activities & \\
\hline 84 & Public administration and defence & Excluded \\
\hline 85 & Education & Other services \\
\hline 86 to 88 & Human health and social work activities & \\
\hline 90 to 93 & Arts, entertainment and recreation & \\
\hline 94 to 96 & Other service activities & \\
\hline
\end{tabular}


Table A5. Sectoral taxonomy of digital intensity: global indicator

\begin{tabular}{|c|c|c|c|c|}
\hline Sector denomination & ISIC rev.4 & $\begin{array}{l}\text { Quartile } \\
\text { of digital } \\
\text { intensity: } \\
2001-03\end{array}$ & $\begin{array}{l}\text { Quartile } \\
\text { of digital } \\
\text { intensity: } \\
2013-15\end{array}$ & $\begin{array}{l}\text { Top quartile } \\
\text { of digital } \\
\text { intensity: } \\
\text { combined } \\
2001-03 \text { and } \\
2013-15\end{array}$ \\
\hline Agriculture, forestry, fishing & 01-03 & Low & Low & Other \\
\hline Mining and quarrying & 05-09 & Low & Low & Other \\
\hline $\begin{array}{l}\text { Food products, beverages and } \\
\text { tobacco }\end{array}$ & $10-12$ & Low & Low & Other \\
\hline $\begin{array}{l}\text { Textiles, wearing apparel, } \\
\text { leather }\end{array}$ & $13-15$ & Medium-low & Medium-low & Other \\
\hline $\begin{array}{l}\text { Wood and paper products, and } \\
\text { printing }\end{array}$ & $16-18$ & Medium-high & Medium-high & Other \\
\hline $\begin{array}{l}\text { Coke and refined petroleum } \\
\text { products }\end{array}$ & 19 & Medium-low & Medium-low & Other \\
\hline $\begin{array}{l}\text { Chemicals and chemical } \\
\text { products }\end{array}$ & 20 & Medium-low & Medium-low & Other \\
\hline Pharmaceutical products & 21 & Medium-low & Medium-low & Other \\
\hline Rubber and plastics products & $22-23$ & Medium-low & Medium-low & Other \\
\hline $\begin{array}{l}\text { Basic metals and fabricated } \\
\text { metal products }\end{array}$ & $24-25$ & Medium-low & Medium-low & Other \\
\hline $\begin{array}{l}\text { Computer, electronic and } \\
\text { optical products }\end{array}$ & 26 & High & Medium-high & High \\
\hline Electrical equipment & 27 & Medium-high & Medium-high & Other \\
\hline $\begin{array}{l}\text { Machinery and equipment } \\
\text { n.e.c. }\end{array}$ & 28 & High & Medium-high & High \\
\hline Transport equipment & $29-30$ & High & High & High \\
\hline $\begin{array}{lr}\text { Furniture; } & \text { other } \\
\text { manufacturing; } & \text { repairs } \\
\text { of computers } & \end{array}$ & $31-33$ & Medium-high & Medium-high & Other \\
\hline $\begin{array}{l}\text { Electricity, gas, steam and air } \\
\text { cond. }\end{array}$ & 35 & Low & Low & Other \\
\hline $\begin{array}{l}\text { Water supply; sewerage, } \\
\text { waste management }\end{array}$ & $36-39$ & Low & Low & Other \\
\hline Construction & $41-43$ & Low & Low & Other \\
\hline
\end{tabular}




\section{Sectoral taxonomy of digital intensity: global indicator (continued)}

\begin{tabular}{|c|c|c|c|c|}
\hline $\begin{array}{l}\text { Wholesale and retail trade, } \\
\text { repair }\end{array}$ & $45-47$ & Medium-high & Medium-high & Other \\
\hline Transportation and storage & $49-53$ & Low & Low & Other \\
\hline $\begin{array}{l}\text { Accommodation and food } \\
\text { service activities }\end{array}$ & $55-56$ & Low & Low & Other \\
\hline $\begin{array}{l}\text { Publishing, audiovisual and } \\
\text { broadcasting }\end{array}$ & $58-60$ & Medium-high & Medium-high & Other \\
\hline Telecommunications & 61 & High & High & High \\
\hline $\begin{array}{l}\text { IT and other information } \\
\text { services }\end{array}$ & $62-63$ & High & High & High \\
\hline Finance and insurance & $64-66$ & High & High & High \\
\hline Real estate & 68 & Low & Low & Other \\
\hline $\begin{array}{l}\text { Legal and accounting } \\
\text { activities, etc. }\end{array}$ & $69-71$ & High & High & High \\
\hline $\begin{array}{l}\text { Scientific research and } \\
\text { development }\end{array}$ & 72 & Medium-high & High & High \\
\hline $\begin{array}{l}\text { Advertising and market } \\
\text { research; other business } \\
\text { services }\end{array}$ & $73-75$ & High & High & High \\
\hline $\begin{array}{l}\text { Administrative and support } \\
\text { service activities }\end{array}$ & $77-82$ & High & High & High \\
\hline $\begin{array}{l}\text { Public administration and } \\
\text { defence }\end{array}$ & 84 & Medium-high & Medium-high & Other \\
\hline Education & 85 & Medium-low & Medium-low & Other \\
\hline Human health activities & 86 & Medium-high & Medium-low & Other \\
\hline $\begin{array}{l}\text { Residential care and social } \\
\text { work activities }\end{array}$ & $87-88$ & Medium-low & Medium-low & Other \\
\hline $\begin{array}{l}\text { Arts, entertainment and } \\
\text { recreation }\end{array}$ & $90-93$ & Medium-low & Medium-high & Other \\
\hline Other service activities & $94-96$ & Medium-high & High & High \\
\hline
\end{tabular}

Note: In the first two columns, "high" identifies sectors in the top quartile of the distribution of the values underpinning the global taxonomy, "medium-high" the second highest quartile, "medium-low" the second lowest, and "low" the bottom quartile. The third column reports the digital intensity measure used in the current paper, based on a combination of the first and second column.

Source: Calvino et al. (2018a). 


\section{Figure A1. Business dynamics - digital intensive vs. other sectors}

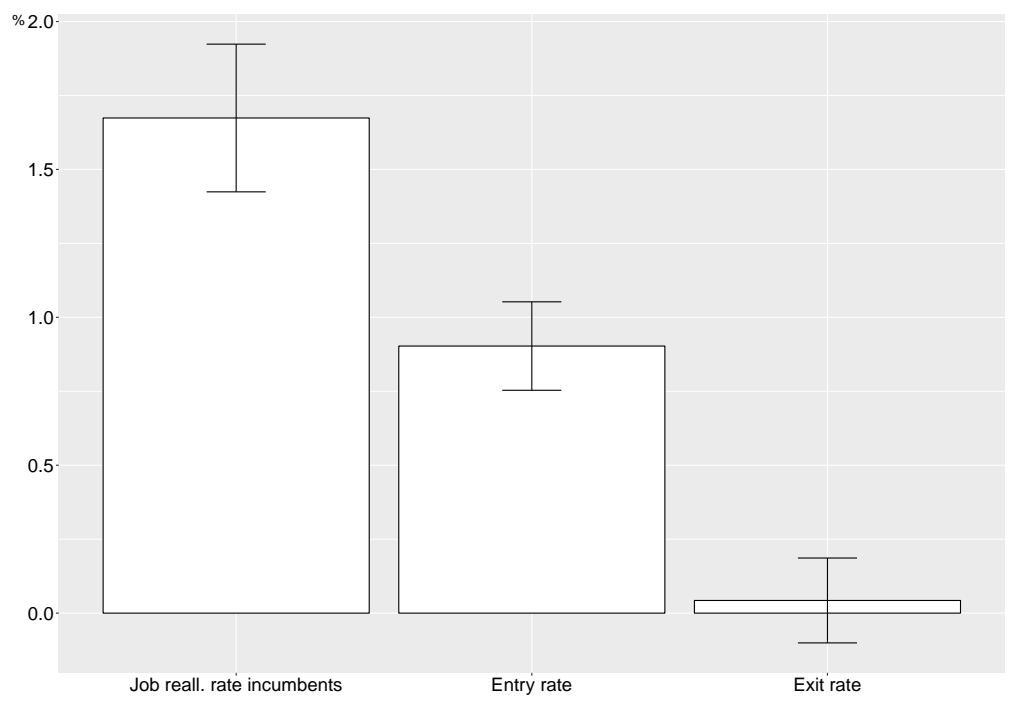

Note: The bars report coefficients based on separate regressions where the dependent variables are alternatively job reallocation rates of incumbents, entry rates or exit rates, which are regressed on a digital intensity dummy as defined above. The regressions include as controls a manufacturing vs. services dummy and country-year fixed effects. Confidence intervals (95\%) are also reported based on robust standard errors. Source: OECD DynEmp3 database, August 2018.

Figure A2. Job reallocation rates - digital intensive vs. other sectors

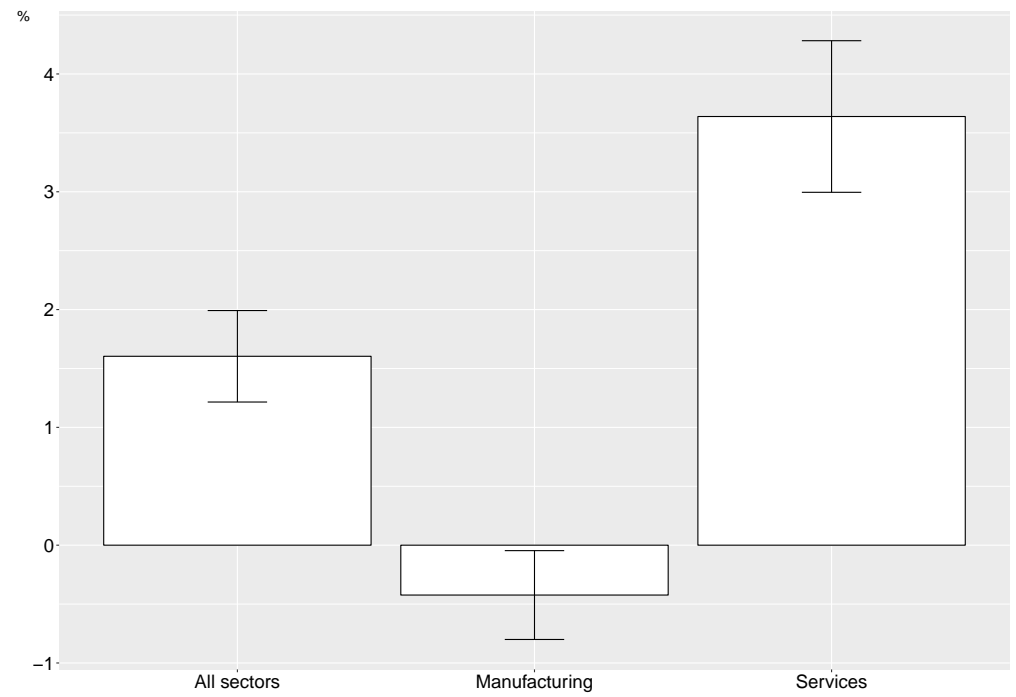

Note: The bars report coefficients based on separate regressions where the dependent variable is overall job reallocation rate regressed on a digital intensity dummy as defined above. The regressions first focus on all sectors including as controls a manufacturing vs. services dummy, then focus on manufacturing and finally on services. All regressions include country-year fixed effects. Confidence intervals $(95 \%)$ are also reported based on robust standard errors.

Source: OECD DynEmp3 database, August 2018. 
Figure A3. Business dynamics variables

(a) Manufacturing

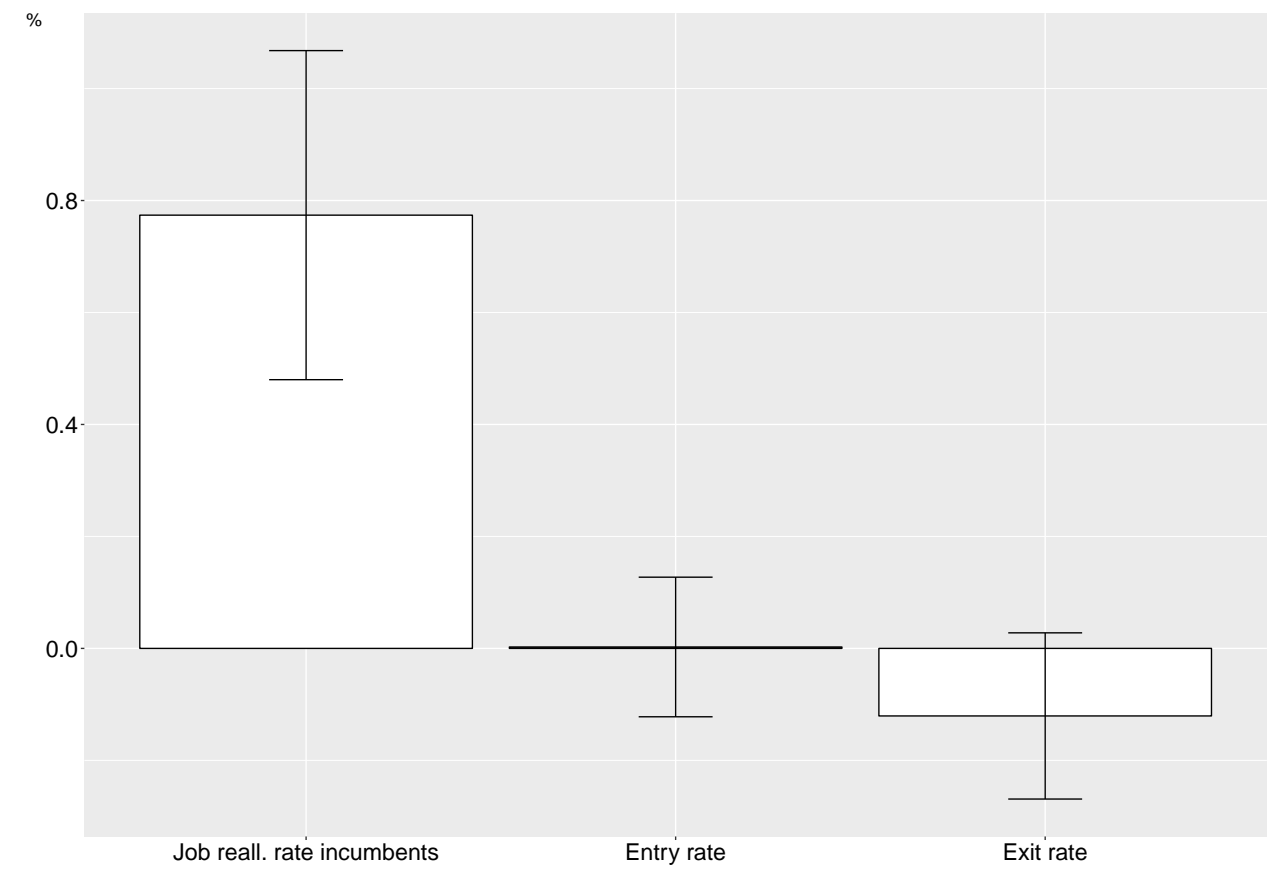

(b) Services

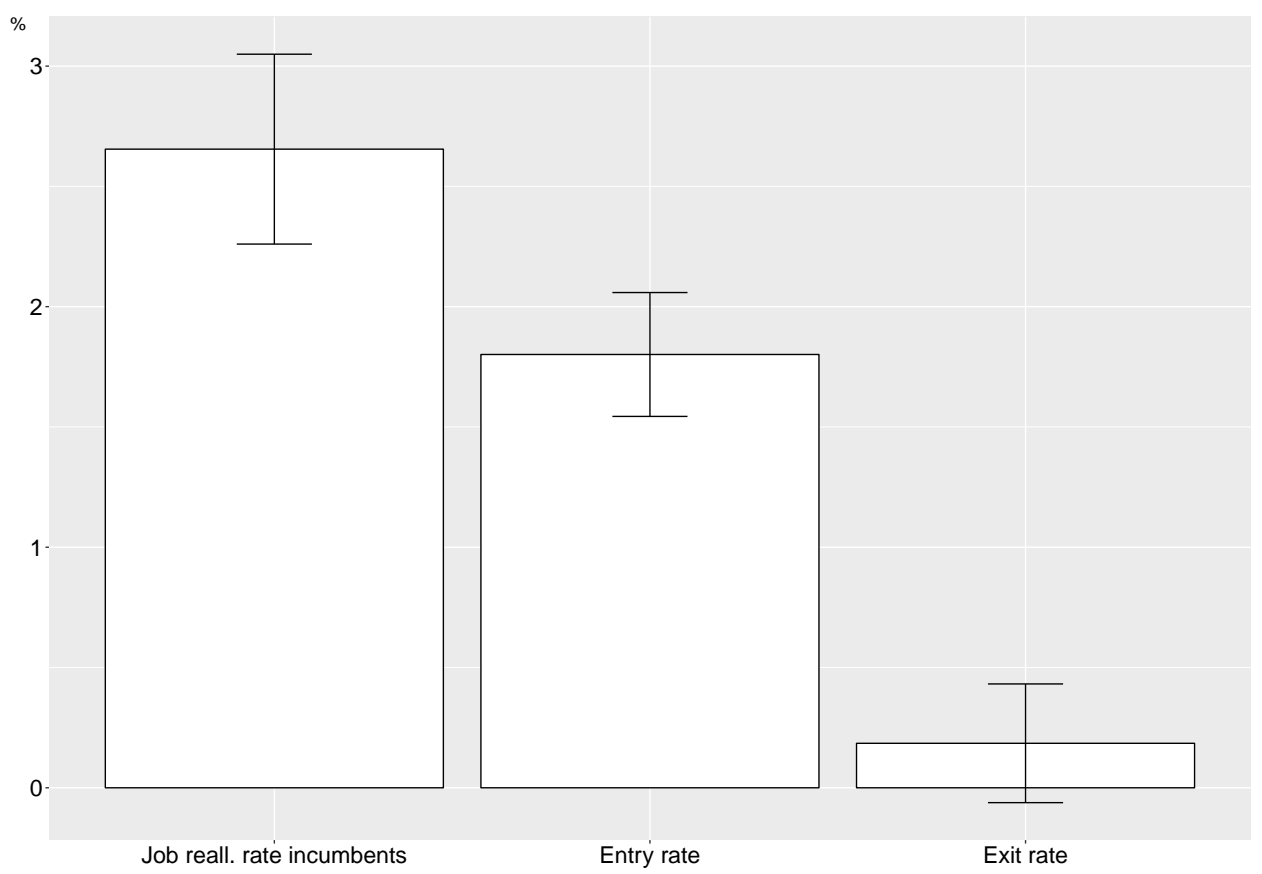

Note: The bars report coefficients based on separate regressions where the dependent variables are alternatively job reallocation rates of incumbents, entry rates or exit rates, which are regressed on a digital intensity dummy as defined above. The regressions first focus on manufacturing and then on services, and include country-year fixed effects. Confidence intervals (95\%) are also reported based on robust standard errors. The focus is on manufacturing (Panel a) and non-financial market services (Panel b).

Source: OECD DynEmp3 database, August 2018. 
Figure A4. Estimated elasticity of Job reallocation rates of incumbents to different dimensions of digital intensity

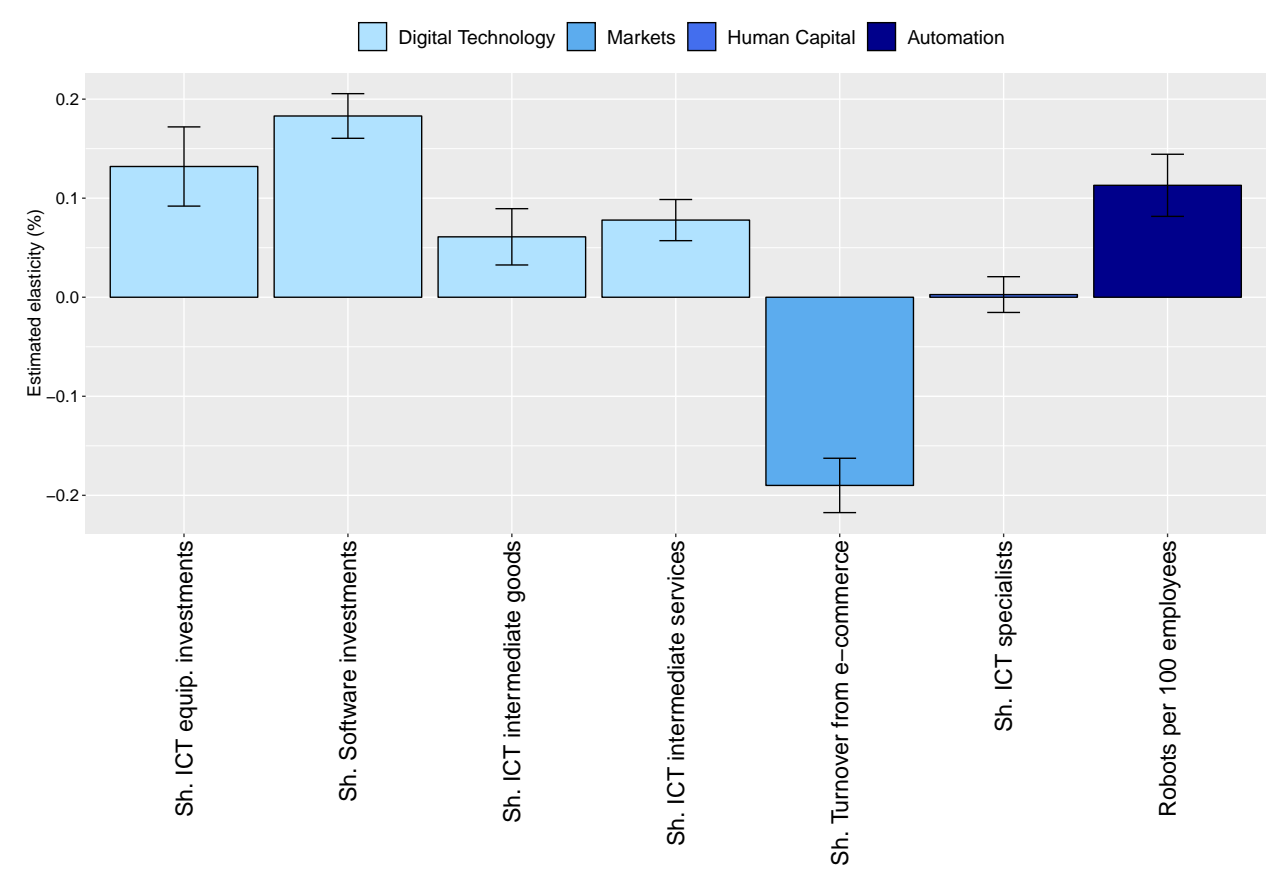

Note: The bars report coefficients (elasticities) based on separate regressions where the dependent variable is (the $\log$ of) job reallocation rates of incumbents, while the dependent variables are (the log of) different digital intensity measures, as described in the text. The regressions include as controls a manufacturing vs. services dummy and country-year fixed effects. Confidence intervals $(95 \%)$ are also reported based on robust standard errors.

Source: OECD DynEmp3 database, August 2018. 
Table A6. Average business dynamism by digital intensity - Before 2004

\begin{tabular}{lcc|cc}
\hline & Digital & Other & \\
\hline & mean & std. dev. & mean & std. dev. \\
Job reallocation rates of incumbents (\%) & 18.1 & 6.7 & 13.6 & 4.6 \\
Entry rates (\%) & 9.3 & 5.0 & 6.2 & 3.4 \\
Exit rates (\%) & 6.4 & 3.7 & 5.7 & 2.7 \\
\hline
\end{tabular}

Note: The table reports unweighted averages and standard deviations of job reallocation rates of incumbents, entry rates, and exit rates across countries, STAN a38 sectors, and years focusing on the Digital intensive group and on Other sectors before 2004.

Source: OECD DynEmp3 database, August 2018.

Table A7. Average business dynamism by digital intensity - After 2009

\begin{tabular}{lcc|cc}
\hline & Digital & Other \\
\hline & mean & std. dev. & mean & std. dev. \\
Job reallocation rates of incumbents (\%) & 15.7 & 6.0 & 13.1 & 5.0 \\
Entry rates (\%) & 7.1 & 4.6 & 5.3 & 3.2 \\
Exit rates (\%) & 6.9 & 3.7 & 6.1 & 2.4 \\
\hline
\end{tabular}

Note: The table reports unweighted averages and standard deviations of job reallocation rates of incumbents, entry rates, and exit rates across countries, STAN a38 sectors, and years focusing on the Digital intensive group and on Other sectors after 2009.

Source: OECD DynEmp3 database, August 2018. 


\section{Figure A5. Change in business dynamism - Average trends}

(a) Job reallocation rate - All firms

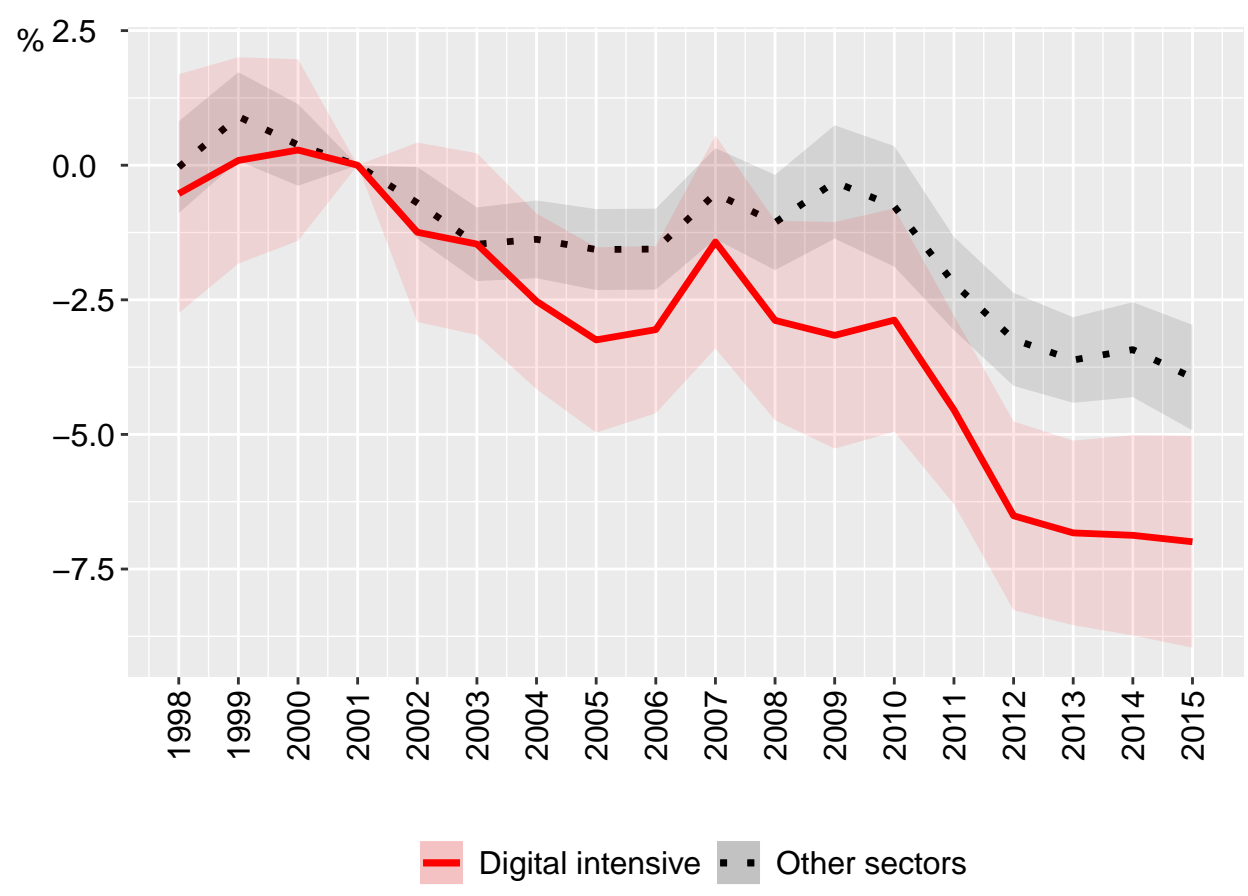

Note: The figure reports average within-country-industry trends, based on the year coefficients of regressions within country-sector, with and without interaction with the digital intensity dummy. Digital intensive sectors are reported with a solid line and other sectors with a dashed line. The dependent variable is overall job reallocation rate. Confidence bands (95\%) are also reported based on robust standard errors. The baseline year is set to 2001.

Source: OECD DynEmp3 database, August 2018. 
Table A8. Summary of policy variables

\begin{tabular}{|c|c|c|c|}
\hline Policy variable & Source & Definition & Coverage \\
\hline $\begin{array}{lll}\begin{array}{l}\text { Average } \\
\text { schooling }\end{array} & \text { years } & \text { of } \\
\end{array}$ & $\begin{array}{l}\text { Morrisson and Murtin } \\
(2009)\end{array}$ & $\begin{array}{l}\text { Measures average years } \\
\text { of schooling, including } \\
\text { higher education and taking } \\
\text { into account differential } \\
\text { mortality across educational } \\
\text { groups. }\end{array}$ & $\begin{array}{l}\text { 1998-2011. Missing } \\
\text { values have been } \\
\text { interpolated. }\end{array}$ \\
\hline $\begin{array}{l}\text { Government } \\
\text { expenditure per } \\
\text { student, secondary ( } \% \\
\text { of GDP per capita) }\end{array}$ & $\begin{array}{l}\text { World Bank, World } \\
\text { Development Indicators }\end{array}$ & $\begin{array}{l}\text { Represents the education } \\
\text { input by the government. }\end{array}$ & $\begin{array}{l}\text { 1998-2014; } \\
\text { 2001-2014 } \\
\text { (except 2012) }\end{array}$ \\
\hline $\begin{array}{l}\text { Higher education } \\
\text { expenditure on R\&D } \\
\text { as a percentage of } \\
\text { GDP }\end{array}$ & $\begin{array}{l}\text { OECD, Main Science and } \\
\text { Technology Indicators. }\end{array}$ & $\begin{array}{l}\text { Represents the component of } \\
\text { gross domestic expenditure } \\
\text { on R\&D (GERD) incurred } \\
\text { by units belonging to the } \\
\text { higher education sector } \\
\text { during a specific period. }\end{array}$ & $\begin{array}{l}\text { 1998-2015; } \\
\text { 1998-2014 TUR; } \\
\text { n/a BRA, CRI. } \\
\text { Missing values have } \\
\text { been interpolated. }\end{array}$ \\
\hline $\begin{array}{l}\text { Workplace training ( \% } \\
\text { of GDP) }\end{array}$ & $\begin{array}{l}\text { OECD, Database on Labour } \\
\text { Market Programmes }\end{array}$ & $\begin{array}{l}\text { Measures expenditures } \\
\text { on workplace training as } \\
\text { percent of GDP. }\end{array}$ & $\begin{array}{l}\text { 1998-2015; } \\
2004-2015 \quad \text { HUN; } \\
2002-2015 \text { JPN; n/a } \\
\text { BRA, CRI, TUR }\end{array}$ \\
\hline $\begin{array}{l}\text { Venture } \\
\text { finance, early } \begin{array}{r}\text { capital } \\
\text { stages }\end{array}\end{array}$ & Saia et al. (2015) & $\begin{array}{l}\text { Measures venture capital in } \\
\text { pre-seed, seed, start-up and } \\
\text { other early stages. }\end{array}$ & $\begin{array}{l}2005 \text { only (values } \\
\text { are repeated for other } \\
\text { years); n/a BRA, CRI, } \\
\text { TUR }\end{array}$ \\
\hline $\begin{array}{l}\text { Commercial bank } \\
\text { branches (per } 100,000 \\
\text { adults) }\end{array}$ & $\begin{array}{l}\text { World Bank, World } \\
\text { Development Indicators }\end{array}$ & $\begin{array}{l}\text { Retail locations of resident } \\
\text { commercial banks and } \\
\text { other resident banks that } \\
\text { function as commercial } \\
\text { banks that provide financial } \\
\text { services to customers and } \\
\text { are physically separated } \\
\text { from the main office but } \\
\text { not organised as legally } \\
\text { separated subsidiaries. }\end{array}$ & $\begin{array}{l}\text { 2004-2016; BEL } \\
\text { 2007-2016; BRA, } \\
\text { TUR 2005-2016 }\end{array}$ \\
\hline $\begin{array}{l}\text { Product market } \\
\text { regulation (PMR) }\end{array}$ & $\begin{array}{l}\text { OECD, Product Market } \\
\text { Regulation (PMR) Database }\end{array}$ & $\begin{array}{l}\text { Measures the simple average } \\
\text { across the three high-level } \\
\text { indicators state control, } \\
\text { barriers to entrepreneurship } \\
\text { and barriers to trade and } \\
\text { investment. }\end{array}$ & $\begin{array}{lr}\text { 1998, } 2003, \quad 2008, \\
2013 ; & 2008-2013 \\
\text { BRA; } & \text { n/a CRI }\end{array}$ \\
\hline $\begin{array}{l}\text { Administrative } \\
\text { burdens on startups } \\
\text { (PMR) }\end{array}$ & $\begin{array}{l}\text { OECD, Product Market } \\
\text { Regulation (PMR) Database }\end{array}$ & $\begin{array}{l}\text { Includes administrative } \\
\text { burdens for corporations, } \\
\text { administrative burdens for } \\
\text { sole proprietor firms and } \\
\text { barriers in services sectors. }\end{array}$ & $\begin{array}{lr}1998, & 2003, \quad 2008 \\
2013 ; & 2008-2013 \\
\text { BRA; n/a CRI }\end{array}$ \\
\hline
\end{tabular}




\section{(continues)}

\begin{tabular}{|c|c|c|c|}
\hline Policy variable & Source & Definition & Coverage \\
\hline $\begin{array}{l}\text { Stocks traded, total } \\
\text { value }(\% \text { of GDP) }\end{array}$ & $\begin{array}{l}\text { World Bank, World } \\
\text { Development Indicators }\end{array}$ & $\begin{array}{l}\text { Total number of shares } \\
\text { traded, both domestic and } \\
\text { foreign, multiplied by } \\
\text { their respective matching } \\
\text { prices (only one side of the } \\
\text { transaction is considered, } \\
\text { end of year values). } \\
\text { Companies admitted to } \\
\text { listing and admitted to } \\
\text { trading are included in the } \\
\text { data. }\end{array}$ & $\begin{array}{l}\text { 1998-2016; } r \text { BEL, } \\
\text { FRA, ITA, NDL, } \\
\text { PRT 1998-2014; } \\
\text { CRI 1998-1999 and } \\
\text { 2003-2013; FIN, SWE } \\
\text { 1998-2004; HUN } \\
\text { 2002-2016 }\end{array}$ \\
\hline Business regulations & $\begin{array}{l}\text { Fraser Institute, Economic } \\
\text { Freedom of the World } \\
(\mathrm{EFW}) \text { index }\end{array}$ & $\begin{array}{l}\text { Measures business } \\
\text { regulation in administrative } \\
\text { requirements, bureaucracy } \\
\text { costs, starting a business, } \\
\text { extra payments, licensing } \\
\text { restrictions, and cost of tax } \\
\text { compliance. }\end{array}$ & $2000-2015$ \\
\hline $\begin{array}{l}\text { Enforcing contracts, } \\
\text { time (days) }\end{array}$ & $\begin{array}{l}\text { World Bank, Doing Business } \\
\text { (2017) }\end{array}$ & $\begin{array}{l}\text { Measures the time for } \\
\text { resolving a commercial } \\
\text { dispute through a local } \\
\text { first-instance court. }\end{array}$ & $2004-2015$ \\
\hline $\begin{array}{l}1-\text { B-index of } \\
\text { innovation support for } \\
\text { large firms }\end{array}$ & $\begin{array}{l}\text { OECD, Main Science and } \\
\text { Technology Indicators }\end{array}$ & $\begin{array}{l}\text { This is a measure of R\&D tax } \\
\text { generosity (Warda, 2001). } \\
\text { The B-index represents the } \\
\text { required rate of pre-tax } \\
\text { return to justify } \$ 1 \text { of } R \& D \\
\text { outlay taking account of both } \\
\text { R\&D tax incentives and the } \\
\text { corporate income tax rate. } \\
\text { Consequently, an increase } \\
\text { in R\&D tax incentives is } \\
\text { reflected by a decline in the } \\
\text { B-index. }\end{array}$ & $\begin{array}{l}\text { 1998-2011; HUN } \\
\text { 2004-2011; n/a Brazil, } \\
\text { CRI, TUR }\end{array}$ \\
\hline $\begin{array}{lr}\begin{array}{l}\text { Strictness } \\
\text { and }\end{array} & \text { Individual } \\
\text { dismissals } & \text { regular } \\
\text { contracts version 1 }\end{array}$ & $\begin{array}{l}\text { OECD, Employment } \\
\text { Protection Database }\end{array}$ & $\begin{array}{l}\text { Synthetic indicator of the } \\
\text { strictness of regulation on } \\
\text { dismissals and the use of } \\
\text { temporary contracts, refers } \\
\text { to the regulation in force on } \\
\text { the } 1 \text { st of January each year. }\end{array}$ & $\begin{array}{l}1998-2013 ; \\
2008-2012 \\
2014 \text { CRI }\end{array}$ \\
\hline $\begin{array}{l}\text { Resolving insolvency, } \\
\text { time (years) }\end{array}$ & World Bank, Doing Business & $\begin{array}{l}\text { Number of years from the } \\
\text { filing for insolvency in } \\
\text { court until the resolution of } \\
\text { distressed assets. }\end{array}$ & $\begin{array}{l}\text { 2004-2016; BRA, JPN } \\
\text { 2014-2016 }\end{array}$ \\
\hline
\end{tabular}


Table A9. Descriptive statistics policy variables

\begin{tabular}{|c|c|c|c|c|c|c|}
\hline Policy variable & $\mathbf{N}$ & Mean & Std. Dev. & L. Year & Minimum & Maximum \\
\hline Years of schooling & 147 & 10.69 & 1.80 & 2010 & 6.75 (TUR) & $13.15(\mathrm{JPN})$ \\
\hline Gov. Exp. Secondary Educ. & 174 & 25.54 & 5.18 & 2013 & 14.77 (TUR) & $34.70(\mathrm{FIN})$ \\
\hline Higher Educ. Exp. in R\&D & 184 & 0.479 & 0.171 & 2015 & 0.167 (HUN) & 0.876 (SWE) \\
\hline Workplace training & 169 & 0.018 & 0.024 & 2015 & 0 (HUN,NLD) & 0.120 (PRT) \\
\hline Venture capital & 176 & 0.022 & 0.016 & 2005 & 0.002 (ITA,NLD) & $0.052(\mathrm{SWE})$ \\
\hline Commercial banks & 156 & 31.09 & 23.61 & 2015 & $6.55(\mathrm{FIN})$ & $67.51(\mathrm{ESP})$ \\
\hline PMR (overall) & 40 & 1.69 & 0.46 & 2013 & 0.915 (NLD) & 2.543 (BRA) \\
\hline PMR (Ad. Burden startups) & 40 & 2.31 & 0.56 & 2013 & 1.248 (NLD) & 3.080 (TUR) \\
\hline Size of stock market & 182 & 44.43 & 35.68 & 2014 & $0.133(\mathrm{CRI})$ & $99.917(\mathrm{JPN})$ \\
\hline Business regulations & 201 & 6.74 & 1.11 & 2015 & 3.481 (BRA) & $8.432(\mathrm{FIN})$ \\
\hline Contract enforcement & 140 & 532.30 & 264.10 & 2015 & 280 (NOR) & 1185 (ITA) \\
\hline Large firm support for innovation & 131 & 0.105 & 0.129 & 2011 & $-0.015(\mathrm{SWE})$ & 0.425 (FRA) \\
\hline EPL & 171 & 2.38 & 0.65 & 2013 & $1.369(\mathrm{JPN})$ & $3.185(\mathrm{PRT})$ \\
\hline Bankruptcy regulations & 140 & 1.76 & 0.83 & 2015 & $0.6(\mathrm{JPN})$ & 4 (BRA) \\
\hline
\end{tabular}

Note: The column "L. year" reports the latest available year. Minimum and maximum are based on the latest available year. 
Table A10. Policy regressions results

\begin{tabular}{|c|c|c|c|c|}
\hline & log EntryRate & log EntryRate & log EntryRate & log EntryRate \\
\hline Policy $\times$ Digital & $\begin{array}{l}0.0754^{* * *} \\
(0.0107)\end{array}$ & $\begin{array}{l}0.0956^{* * *} \\
(0.0105)\end{array}$ & $\begin{array}{l}0.0451^{* * *} \\
(0.00899)\end{array}$ & $\begin{array}{l}0.0267^{* * *} \\
(0.0103)\end{array}$ \\
\hline Observations & 2,979 & 3,477 & 3,730 & 3,420 \\
\hline R-squared & 0.819 & 0.804 & 0.807 & 0.791 \\
\hline Policy & $\begin{array}{l}\text { Years of } \\
\text { schooling }\end{array}$ & $\begin{array}{l}\text { Gov. Exp. } \\
\text { Secondary Educ. }\end{array}$ & $\begin{array}{l}\text { Higher Educ. } \\
\text { Exp. in R\&D }\end{array}$ & Workplace training \\
\hline Exposure Lab & Digital intensity & Digital intensity & Digital intensity & Digital intensity \\
\hline Fixed Effects & $\mathrm{C} \times \mathrm{Y} \mathrm{S}$ & $\mathrm{C} \times \mathrm{YS}$ & $\mathrm{C} \times \mathrm{Y} \mathrm{S}$ & $\mathrm{C} \times \mathrm{Y} \mathrm{S}$ \\
\hline & log EntryRate & log EntryRate & log EntryRate & log EntryRate \\
\hline Policy $\times$ Digital & $\begin{array}{l}0.0532^{* * * *} \\
(0.00958)\end{array}$ & $\begin{array}{l}0.00584 \\
(0.00971)\end{array}$ & $\begin{array}{l}0.0312^{* * *} \\
(0.00995)\end{array}$ & $\begin{array}{l}-0.0375^{*} \\
(0.0199)\end{array}$ \\
\hline Observations & 3,556 & 3,188 & 3,680 & 827 \\
\hline R-squared & 0.797 & 0.801 & 0.809 & 0.808 \\
\hline Policy & Venture capital & Commercial banks & Size of stock market & PMR (overall) \\
\hline Exposure & Digital intensity & Digital intensity & Digital intensity & Digital intensity \\
\hline Fixed Effects & $\mathrm{C} \times \mathrm{Y} \mathrm{S}$ & $\mathrm{C} \times \mathrm{YS}$ & $\mathrm{C} \times \mathrm{Y} \mathrm{S}$ & $\mathrm{C} \times \mathrm{Y} \mathrm{S}$ \\
\hline
\end{tabular}

\begin{tabular}{|c|c|c|c|}
\hline & log EntryRate & log EntryRate & log EntryRate \\
\hline Policy $\times$ Digital & $\begin{array}{l}-0.0407^{* *} \\
(0.0190)\end{array}$ & $\begin{array}{l}0.0745^{* * *} \\
(0.00879)\end{array}$ & $\begin{array}{l}-0.0474^{* * *} \\
(0.0129)\end{array}$ \\
\hline Observations & 827 & 4,065 & 2,947 \\
\hline R-squared & 0.808 & 0.805 & 0.789 \\
\hline Policy & $\begin{array}{l}\text { PMR (Ad. } \\
\text { startups) }\end{array}$ & Business regulations & Enf. contracts \\
\hline Exposure & Digital intensity & Digital intensity & $\begin{array}{l}\text { (days) } \\
\text { Digital intensity }\end{array}$ \\
\hline Fixed Effects & $\mathrm{C} \times \mathrm{Y} \mathrm{S}$ & $\mathrm{C} \times \mathrm{Y} \mathrm{S}$ & $\mathrm{C} \times \mathrm{Y} \mathrm{S}$ \\
\hline & log EntryRate & log EntryRate & log EntryRate \\
\hline Policy $x$ Digital & $\begin{array}{l}-0.0369^{* * *} \\
(0.0101)\end{array}$ & $\begin{array}{l}0.0170 \\
(0.0109)\end{array}$ & $\begin{array}{l}-0.0858^{* * *} \\
(0.0121)\end{array}$ \\
\hline Observations & 2,618 & 3,458 & 2,947 \\
\hline R-squared & 0.803 & 0.807 & 0.792 \\
\hline Policy & $\begin{array}{l}\text { Large firm support } \\
\text { for innovation }\end{array}$ & EPL & Bankruptcy regulations \\
\hline Exposure & Digital intensity & Digital intensity & Digital intensity \\
\hline Fixed Effects & $\mathrm{C} \times \mathrm{Y} \mathrm{S}$ & $\mathrm{C} \times \mathrm{Y} \mathrm{S}$ & $\mathrm{C} \times \mathrm{Y} \mathrm{S}$ \\
\hline
\end{tabular}




\section{Robustness checks - Policy regression results}

This section discusses an extensive number of robustness checks that have been carried out to test the robustness of the policy regression findings presented in Figure 7 in the main body of text (see also Table A10).

These include:

- estimating the model in Equation 1 with a different set of fixed effects (country, sector, year)

- using the first lag of policy variables instead of contemporaneous values to address possible simultaneity issues

- using an alternative continuous exposure variable (the share of ICT investments in non-residential gross fixed capital formation) instead of the digital intensity dummy as exposure variable ${ }^{45}$

- estimating the regressions on a common sample ${ }^{46}$

- using a logarithmic transformation also to the relevant policy variables

- applying an inverse hyperbolic sine transformation instead of the logarithmic transformation to the dependent variable, to deal with observations with zero value following Card and Della Vigna (2017).

Overall these tests, which are available upon request, qualitatively confirm the results presented in Figure 7. 


\title{
Notes
}

\author{
${ }^{1}$ See the analysis by Jovanovic and Rousseau (2005) for a comparison between electrification and the \\ IT era. \\ ${ }^{2}$ See Decker et al. (2016) and Decker et al. (2018) for evidence on declining business dynamism in \\ the United States; see Bessen (2017) and Calligaris et al. (2018) for evidence on changes in the market \\ environment.
}

${ }^{3}$ Austria, Belgium, Brazil, Costa Rica, Finland, France, Hungary, Italy, Japan, the Netherlands, Norway, Portugal, Spain, Sweden, Turkey. Information for most countries is aggregated from firm-level data, while for Austria and Japan information is based on plant-level data. For Japan, only the manufacturing sector is available.

${ }^{4}$ Digital intensive sectors, as further discussed in the following, include Computer and electronics; Machinery and equipment n.e.c.; Transport equipment; Telecommunication; IT; Legal and accounting; Scientific R\&D; Marketing and other business services; Administrative and support services.

${ }^{5}$ Digitalisation is the use of digital technologies and data as well as interconnection that results in new or changes to existing activities (see OECD, 2018).

${ }^{6}$ For complementary approaches see IMF (2018) focusing on online platforms, platform-enabled services, and suppliers of ICT goods and services and see McKinsey (2015) for a multi-dimensional analysis focused on the United States.

${ }^{7}$ On employment dynamics, see Sabadash (2013); Spiezia and Vivarelli (2002) for surveys; see also the more recent work by Frey and Osborne (2017) and Arntz et al. (2016). On composition of employment, see Michaels et al. (2014); Autor et al. (2006). On productivity, see Biagi (2013) and Draca et al., 2009 for surveys.

${ }^{8} \mathrm{~A}$ different branch of the literature has also focused on the effect of ICTs and organisational change on job and worker flows (Askenazy and Galbis, 2007, Bauer and Bender, 2004).

${ }^{9}$ A previous paper by Gort and Klepper (1982) focuses instead on the dynamics of the diffusion of new products. Their framework has been recently applied by Foster et al. (2018) to study the dynamics of entry, productivity dispersion and productivity growth in the US economy, in the context of the ongoing debate on the productivity slowdown.

${ }^{10}$ DynEmp is a distributed micro-data project led by the OECD Directorate for Science, Technology and Innovation with the essential contribution of country delegates and national experts from OECD and non-OECD countries. Additional details on the DynEmp approach are discussed hereafter in Box 1. The data are based on the DynEmp3 data collection. Data for some countries are still preliminary.

${ }^{11}$ Information for most countries is aggregated from firm-level data, while for Austria and Japan information is based on plant-level data. For Japan, only the manufacturing sector is available. Additional methodological information is available in the Appendix.

${ }^{12}$ Defined as the sum of job creation and job destruction rates of incumbents. See the Appendix for more details.

${ }^{13}$ In order to derive aggregate implications, reference is also made to overall job reallocation (including information for entering, incumbent and exiting firms) as a measure of the simultaneous job creation and job destruction occurring within an industry (see also Decker et al., 2018).

${ }^{14}$ The analysis excludes self-employment due to the existing challenges in measuring it consistently across countries.

${ }^{15}$ The analysis excludes Coke and refined petroleum products and Real estate activities. The rest of the paper refers to manufacturing and services in the sense discussed here. A reference table of all sectors is reported in the Appendix (Table A4).

${ }^{16}$ It is calculated averaging out the position of a given sector in each of the considered dimensions. 
Further details and robustness are provided in Calvino et al. (2018a).

${ }^{17}$ The digital intensity indicator used will be therefore equal to 1 in these sectors, and 0 otherwise.

${ }^{18}$ The graphs reports for each country unweighted averages across sectors and available years, focusing separately on the groups of digital intensive and other sectors, for two periods (before 2004 and after 2009). For Costa Rica, Spain, the Netherlands, and Turkey the first available year is used for the first (before 2004) period. A detailed coverage table is reported in the Appendix (Table A3). Owing to methodological differences, figures may deviate from officially published national statistics. Data for some countries are still preliminary.

${ }^{19}$ The bars reported in Figure A1 are based on separate regressions where the dependent variables are alternatively job reallocation rates of incumbents, entry rates or exit rates, which are regressed on a digital intensity dummy, as defined above. The regressions include as controls a manufacturing vs. services dummy and country-year fixed effects wiping out unobserved country-specific macro-economic shocks.

${ }^{20}$ Statistically significant higher job reallocation rates, job reallocation rates for incumbents and entry rates are also confirmed when using least absolute deviation or robust regressions.

${ }^{21}$ This appears less true for manufacturing, mainly due to lower job destruction rates. Unreported results focusing separately on job creation rates (JCR) and job destruction rates (JDR) for all firms suggest indeed that the lower overall job reallocation in manufacturing comes from lower JDR, while JCRs are instead on average higher in digital intensive sectors, both in manufacturing and services.

${ }^{22}$ Given the overall non-significant results for exit rates, the focus is on job reallocation rates of incumbents and on entry rates. The figures are based on separate regressions of business dynamics variables using each indicator of digital intensity separately as a key explanatory variable. Digital intensity indicators are those reported by Calvino et al. (2018a) on average for the two observed periods, likewise with what discussed above for the summary digital intensity indicator. A logarithmic transformation of variables is used to ease the interpretation of coefficients. As in the figures reported above, all regressions include as additional controls a manufacturing vs. services dummy and country-year fixed effects wiping out unobserved country-specific macro-economic shocks.

${ }^{23}$ These figures are based on separate single-country regressions where the dependent variables are alternatively job reallocation rates of incumbents, entry rates or exit rates, which are regressed on a digital intensity dummy as defined above. The regressions include as controls a manufacturing vs. services dummy and year fixed effects. A certain degree of cross-country variation in time coverage is to be taken into account when comparing country-specific figures (see Table A3 in the Appendix for a detailed coverage table).

${ }^{24}$ The figures are based on the year coefficients of regressions within country-sector, with and without interaction with the digital intensity dummy.

${ }^{25}$ See also Table A6 and Table A7 in the Appendix.

${ }^{26}$ Unreported robustness checks qualitatively confirm the declining trends in entry rates and job reallocation rates of incumbents in digital intensive sectors when focusing on median values. Unreported analysis suggests that separately focusing on digital intensive manufacturing and services provides qualitatively similar insights, especially in the case of digital intensive services, and that using the share of employment of entrants rather than entry rates qualitatively confirms the overall findings.

${ }^{27}$ Despite the data do not allow to comprehensively distinguish M\&As from economic entry, it seems reasonable to believe that the difference in trends between digital intensive and other sectors, if anything, would be even more pronounced given the increasing M\&A activity in digital sectors (see Bajgar et al., 2018).

${ }^{28}$ Evidence on the overall job reallocation rates (see Figure A5 in the Appendix) qualitatively confirms these declining trends.

${ }^{29}$ The figures are based on separate single-country regressions where the dependent variables are alternatively job reallocation rates of incumbents, entry rates or exit rates, which are regressed on a dummy that is equal to 0 in the first three years in each countries, and 1 in the last three years. The regressions 
include industry fixed effects and focus on digital intensive sectors. A certain degree of cross-country variation in time coverage is to be taken into account when comparing country-specific figures (see Table A3 in the Appendix for a detailed coverage table).

${ }^{30}$ In Finland, Japan and Norway (job reallocation rates of incumbents) and in Portugal (entry rates) in digital intensive sectors do not present trends that are significantly different from those in other sectors.

${ }^{31}$ This analysis is available upon request from the authors.

${ }^{32}$ Reference to technological change here is to be considered in a broad way. This quantification is based on the adjusted-R squared of regressions of entry rates, including alternatively industry-year fixed effects and country-year fixed effects, abstaining from macro-economic shocks common to all countries and industries in the lower bound.

${ }^{33}$ Despite it is not easy to proxy technological maturity at sectoral level, possible measures may include the share of radical patents (mainly in the manufacturing sector) or the average age of firms at the productivity frontier.

${ }^{34}$ The SPIDER database and details about its construction are presented by Égert et al. (2017); the vintage used in this paper dates 15 June 2018. Additional information on the OECD Indicators of Employment Protection is available at https://www.oecd.org/els/emp/oecdindicatorsofemploymentprotection.htm.

${ }^{35}$ All these policy variables have been standardised in order to ease the interpretation of the regression coefficients.

${ }^{36}$ This is equal to 1 in digital intensive sectors as defined in Section 3 and 0 otherwise.

${ }^{37}$ Coefficients report robust associations and are not causal effects.

${ }^{38}$ Both in terms of overall achievements (years of education) and in terms of quality and innovativeness, proxied by government expenditures in education and R\&D expenditures by higher education institutions.

${ }^{39}$ Somehow more surprisingly, employment protection legislation does not seem significantly related to entry rates in digital intensive sectors vis-à-vis other sectors of the economy. This is possibly due to its higher effects on the intensive rather than extensive margin.

${ }^{40}$ This relates more directly to the second stylised fact presented. Long differences have been calculated as the differences between the 2013-15 and the 1998-2000 periods, or of the closest 3-years moving windows available. This analysis is not possible for indicators of venture capital availability and product market regulations due to data availability constraints (limited number of available data over time).

${ }^{41}$ In this case, however, two of the education indicators, the insolvency and the innovation support for large firms measures are not statistically different from zero, while the sign of the EPL coefficient becomes negative. Results of this exercise are to be taken with caution given the very low number of observations involved, the heterogeneity in time coverages, and the limited time variation of some of the policy indicators. The results are available upon request.

${ }^{42}$ See Table A9 in the Appendix for descriptive statistics of policy variables.

${ }^{43}$ This is not possible with the DynEmp database alone as its main focus is on employment dynamics, but other data sources can be exploited in conjunction with it.

${ }^{44}$ DynEmp uses the birth year variable, when available in the micro-data, to identify the entry year.

${ }^{45}$ This variable is sourced from Calvino et al. (2018a), used in $\log$ and, consistently with the rest of this analysis, on average over the two available time periods (2001-03 and 2013-15). Here the number of procedures (contract enforcement) and workplace training are not statistically different from zero while EPL and the commercial banks variables becomes statistically significant.

${ }^{46}$ The calculation of the common sample excludes those variables that have been excluded from the long differences estimations due to the availability of too few data points over time. In this case the signs of most estimated coefficients are stable but statistical significance of some policy variables reduces due to the more limited number of observations in the common sample. 


\section{References}

Andrews, D., C. Criscuolo, and P. N. Gal (2016), "The best versus the rest: the global productivity slowdown, divergence across firms and the role of public policy", OECD Productivity Working Paper No. 5, OECD Publishing, Paris, Dor: https://doi.org/10.1787/63629cc9-en.

Arntz, M., T. Gregory, and U. Zierahn (2016), "The Risk of Automation for Jobs in OECD Countries", OECD Social, Employment and Migration Working Papers No. 189, OECD Publishing, Paris, Dor: https://doi.org/10.1787/5jlz9h56dvq7-en.

Askenazy, P. and E. M. Galbis (2007), "The Impact of Technological and Organizational Changes on Labor Flows. Evidence on French Establishments", Labour, Vol. 21, No. 2, pp. 265-301.

Autor, D., D. Dorn, L. F. Katz, C. Patterson, and J. Van Reenen (2017), "The fall of the labor share and the rise of superstar firms", NBER Working Paper No. 23396, National Bureau of Economic Research.

Autor, D., L. F. Katz, and M. S. Kearney (2006), "The polarization of the US labor market", American Economic Review, Vol. 96, No. 2, pp. 189-194.

Bajgar, M., G. Berlingieri, S. Calligaris, C. Criscuolo, and J. Timmis (2019), "Industry Concentration in Europe and North America", OECD Productivity Working Papers No. 18, OECD Publishing, Paris, DoI: https://doi.org/10.1787/2ff98246-en.

Bajgar, M., C. Criscuolo, and J. Timmis (2018), "Mergers and acquisitions: Implications for innovation and competition in the digital economy - Scoping paper", Unpublished.

Bartelsman, E. (2013), “ICT, reallocation and productivity”, European Economy-Economic Papers No. 486, European Commission.

Bauer, T. K. and S. Bender (2004), "Technological change, organizational change, and job turnover", Labour Economics, Vol. 11, No. 3, pp. 265-291.

Berlingieri, G., P. Blanchenay, and C. Criscuolo (2017), "The great divergence(s)”, OECD Science, Technology and Industry Policy Papers No. 39, OECD Publishing, Paris, Dor: https://doi.org/ 10.1787/953f3853-en.

Bessen, J. E. (2017), "Information technology and industry concentration", Law and Economics Paper No. 17-41, Boston University School of Law.

Biagi, F. (2013), "ICT and Productivity: A Review of the Literature", Digital Economy Working Paper No. 2013-09, Institute of Prospective Technological Studies, Joint Research Centre.

Bijnens, G. and J. Konings (2018), “Declining Business Dynamism”, CEPR Discussion Paper No. DP12615, Centre for Economic Policy Research.

Bresnahan, T. (2010), "General purpose technologies", in: Handbook of the Economics of Innovation, ed. by B. H. Hall and N. Rosenberg, vol. 2, North-Holland, Amsterdam, pp. 761-791.

Bresnahan, T. and M. Trajtenberg (1995), "General purpose technologies Engines of growth?", Journal of Econometrics, Vol. 65, No. 1, pp. 83-108. 
Brynjolfsson, E. and A. McAfee (2012), Race against the machine: How the digital revolution is accelerating innovation, driving productivity, and irreversibly transforming employment and the economy, Digital Frontier Press, Lexington, MA.

Brynjolfsson, E., A. McAfee, M. Sorell, and F. Zhu (2007), "Scale without mass: business process replication and industry dynamics", Harvard Business School Working Paper No. 07-016, Harvard Business School.

Brynjolfsson, E., D. Rock, and C. Syverson (2017), "Artificial intelligence and the modern productivity paradox: A clash of expectations and statistics", in: Economics of Artificial Intelligence, University of Chicago Press.

Calligaris, S., C. Criscuolo, and L. Marcolin (2018), "Mark-ups in the digital era", OECD Science, Technology and Industry Working Paper No. 2018/10, OECD Publishing, Paris, Dor: https: //doi.org/10.1787/4efe2d25-en.

Calvino, F. and C. Criscuolo (2017), "Measuring regional business employment dynamics from micro-aggregation of administrative data", in: The Geography of Firm Dynamics: Measuring Business Demography for Regional Development, ed. by OECD, OECD Publishing, Paris, chap. 5, pp. 115-150, DoI: https://doi.org/10.1787/9789264286764-7-en.

Calvino, F., C. Criscuolo, L. Marcolin, and M. Squicciarini (2018a), "A taxonomy of digital intensive sectors", OECD Science, Technology and Industry Working Paper No. 2018/14, OECD Publishing, Paris, Dor: https://doi.org/10.1787/f404736a-en.

Calvino, F., C. Criscuolo, and C. Menon (2018b), "A cross-country analysis of start-up employment dynamics”, Industrial and Corporate Change, Vol. 27, No. 4, pp. 677-698.

Calvino, F., C. Criscuolo, and C. Menon (2016), "No country for young firms? Start-up dynamics and national policies." OECD Science, Technology and Industry Policy Papers No. 29, OECD Publishing, Paris, DoI: https://doi.org/10.1787/5jm22p40c8mw-en.

Calvino, F., C. Criscuolo, and R. Verlhac (2018c), "Declining business dynamism: evidence and causes", Unpublished.

Card, D. and S. Della Vigna (2017), "What do Editors Maximize? Evidence from Four Economics Journals”, NBER Working Paper No. 23282, National Bureau of Economic Research.

Cohen, W. M. (2010), "Fifty years of empirical studies of innovative activity and performance", in: Handbook of the Economics of Innovation, ed. by B. H. Hall and N. Rosenberg, vol. 1, North-Holland, Amsterdam, pp. 129-213.

Criscuolo, C., P. N. Gal, and C. Menon (2014), “The Dynamics of Employment Growth", OECD Science, Technology and Industry Policy Papers No. 14, OECD Publishing, Paris, Dor: https: //doi.org/10.1787/5jz417hj6hg6-en.

Decker, R., J. Haltiwanger, R. Jarmin, and J. Miranda (2018), “Changing Business Dynamism and Productivity: Shocks vs. Responsiveness”, NBER Working Paper No. 24236, National Bureau of Economic Research.

Decker, R., J. Haltiwanger, R. Jarmin, and J. Miranda (2016), "Where has all the skewness gone? The decline in high-growth (young) firms in the US", European Economic Review, Vol. 86, pp. 4-23. 
Dosi, G. and R. R. Nelson (2010), "Technical change and industrial dynamics as evolutionary processes", in: Handbook of the Economics of Innovation, ed. by B. H. Hall and N. Rosenberg, vol. 1, North-Holland, Amsterdam, pp. 51-127.

Draca, M., R. Sadun, and J. Van Reenen (2009), "Productivity and ICTs: A review of the evidence", in: The Oxford Handbook of Information and Communication Technologies, ed. by C. Avgerou, R. Mansell, D. Quah, and R. Silverstone, Oxford University Press.

Égert, B., P. Gal, and I. Wanner (2017), "Structural policy indicators database for economic research (SPIDER)", OECD Economics Department Working Papers No. 1429, Dor: https: //doi.org/10.1787/39d69dff-en.

Foster, L., C. Grim, J. Haltiwanger, and Z. Wolf (2018), "Innovation, Productivity Dispersion, and Productivity Growth", NBER Working Paper No. 24420, National Bureau of Economic Research.

Frey, C. B. and M. A. Osborne (2017), "The future of employment: how susceptible are jobs to computerisation?”, Technological Forecasting and Social Change, Vol. 114, pp. 254-280.

Furman, J. and R. Seamans (2018), “AI and the Economy”, NBER Working Paper No. 24689, National Bureau of Economic Research.

Goldfarb, A. and C. Tucker (2017), "Digital economics", NBER Working Paper No. 23684, National Bureau of Economic Research.

Gort, M. and S. Klepper (1982), "Time paths in the diffusion of product innovations", The Economic Journal, Vol. 92, No. 367, pp. 630-653.

Haltiwanger, J., I. Hathaway, and J. Miranda (2014), "Declining business dynamism in the US high-technology sector", Ewing Marion Kauffman Foundation.

Haskel, J. and S. Westlake (2017), Capitalism without capital: the rise of the intangible economy, Princeton University Press.

IMF (2018), "Measuring the digital economy", Policy papers, International Monetary Fund.

Jovanovic, B. and P. L. Rousseau (2005), "General purpose technologies", in: Handbook of economic growth, ed. by P. Aghion and S. N. Durlauf, vol. 1, Elsevier, pp. 1181-1224.

Klepper, S. (2002), "Firm survival and the evolution of oligopoly", RAND Journal of Economics, Vol. 33, No. 1, pp. 37-61.

Klepper, S. (1996), "Entry, exit, growth, and innovation over the product life cycle", The American Economic Review, Vol. 86, No. 3, pp. 562-583.

McKinsey, G. I. (2015), "Digital America: A tale of the haves and have-mores”, Report, McKinsey and Company.

Michaels, G., A. Natraj, and J. Van Reenen (2014), "Has ICT polarized skill demand? Evidence from eleven countries over twenty-five years", Review of Economics and Statistics, Vol. 96, No. 1 , pp. 60-77.

Morrisson, C. and F. Murtin (2009), “The century of education”, Journal of Human Capital, Vol. 3, No. 1, pp. 1-42.

OECD (2018), "Going Digital Synthesis Report: First Draft”, Unpublished. 
Peltoniemi, M. (2011), "Reviewing industry life-cycle theory: Avenues for future research", International Journal of Management Reviews, Vol. 13, No. 4, pp. 349-375.

Pugsley, B. W. and A. Sahin (2019), "Grown-up business cycles”, The Review of Financial Studies, Vol. 32, No. 3, pp. 1102-1147.

Rajan, R. G. and L. Zingales (1998), "Financial Dependence and Growth", The American Economic Review, Vol. 88, No. 3, pp. 559-586.

Sabadash, A. (2013), "ICT-induced technological progress and employment: a happy marriage or a dangerous liaison? A literature review", JRC-IPTS Working Papers No. 2013-09, Institute of Prospective Technological Studies, Joint Research Centre.

Saia, A., D. Andrews, and S. Albrizio (2015), "Productivity spillovers from the global frontier and public policy: Industry-level evidence", OECD Economics Department Working Papers No. 1238, OECD Publishing, Paris, Dor: https://doi.org/10.1787/5js03hkvxhmr-en.

Spiezia, V. and M. Vivarelli (2002), "Innovation and employment: A critical survey", in: Productivity, Inequality and the Digital Economy: A Transatlantic Perspective, ed. by N. Greenan, L. Y., and J. Mairesse, MIT Press, Cambridge, MA, pp. 101-31.

Tukey, J. W. (1977), Exploratory data analysis, Addison-Wesley, Reading, MA.

Tushman, M. L. and P. Anderson (1986), "Technological discontinuities and organizational environments", Administrative Science Quarterly, Vol. 31, No. 3, pp. 439-465.

Van Reenen, J. (2018), "Increasing Differences Between Firms: Market Power and the Macro-Economy", CEP Discussion Paper No. 1576, Centre for Economic Performance, LSE. 